\title{
TRACE ELEMENTS AND SEMI-VOLATILE ORGANIC COMPOUNDS IN BED SEDIMENTS FROM STREAMS AND IMPOUNDMENTS AT FORT GORDON, GEORGIA
}

By James B. McConnell, Timothy C. Stamey, Howard H. Persinger Jr., and Keith W. McFadden

\section{U.S. GEOLOGICAL SURVEY}

Open-File Report 00-87

Prepared in cooperation with

U.S. DEPARTMENT OF THE ARMY

ENVIRONMENTAL AND NATURAL RESOURCES MANAGEMENT

OFFICE OF THE U.S. ARMY SIGNAL CENTER and

FORT GORDON

Cover: U.S. Geological Survey hydrologist collecting bed-sediment samples on tributary to Butler Creek, Fort Gordon, Georgia, May 28, 1998.

Photograph by Timothy C. Stamey, U.S. Geological Survey.

Atlanta, Georgia

2000 


\title{
U.S. DEPARTMENT OF THE INTERIOR Bruce Babbitt, Secretary
}

\section{U.S. GEOLOGICAL SURVEY \\ Charles G. Groat, Director}

\author{
The use of trade names in this report is for descriptive purposes only and does not imply \\ endorsement by the U.S. Government.
}

For additional information, please write to:

District Chief

U.S. Geological Survey

Peachtree Business Center

3039 Amwiler Road, Suite 130

Atlanta, GA 30360-2824
U.S. Geological Survey

Branch of Information Services

Denver Federal Center

Box 25286

Denver, CO 80225-0286 


\section{CONTENTS}

Abstract 1

Introduction 2

Purpose and scope 2

Previous investigations 2

Description of study area 3

Study design 3

General water-quality condition of streams 6

Methods of Investigation $\mathbf{8}$

Basin characterization 8

Bed-sediment samples 8

Bed-sediment- quality-control samples 10

Bed-sediment data-analysis methods $\mathbf{1 0}$

Identification of reference sites 11

Aquatic-life criteria for bed sediment 11

Bed-sediment quality 14

Trace elements 14

Semi-volatile organic compounds 16

Quality-control data for bed-sediment samples $\mathbf{1 7}$

Trace elements 17

Semi-volatile organic compounds 17

Relative ranking of bed-sediment quality $\mathbf{2 2}$

Rankings for trace elements $\mathbf{2 2}$

Rankings for semi-volatile organic compounds $\mathbf{2 4}$

Comparison of trace element and semi-volatile organic compound concentrations to aquatic-life criteria for bed sediment 26

Summary and conclusions $\mathbf{3 1}$

References cited 33

Appendix A. Semi-volatile organic compounds included in chemical analysis of bed-sediment samples, Fort Gordon, Georgia, May 199836

Appendix B. Quality-control data for semi-volatile organic compounds, Fort Gordon, Georgia,

May 199838 


\section{FIGURES}

[Plate is in pocket in back of report]

Plate 1. Concentration of semi-volatile organic compounds in bed-sediment samples, Fort Gordon, Georgia, May 1998

Figures 1-3. Maps showing:

1. Bed-sediment sampling sites, drainage areas, and land use in Fort Gordon, Georgia, study area 4

2. Trace element bed-sediment-quality rankings and aquatic-life criteria comparisons at sampling locations in Fort Gordon, Georgia, study area 29

3. Semi-volatile organic compound (SVOC) bed-sediment-quality rankings and aquatic-life criteria comparisons at sampling locations in Fort Gordon, Georgia, study area $\mathbf{3 0}$

\section{TABLES}

Table 1. Site information for bed-sediment sampling sites, Fort Gordon, Georgia 5

2. Water-quality field data collected at bed-sediment sampling sites $\mathbf{7}$

3. Drainage area and land-use or land-cover characteristics of sampling sites 9

4. Bed-sediment -quality characteristics and associated factors used to develop rankings of bed sediment 10

5. Bed-sediment- quality guidelines for trace elements in bulk sediment $\mathbf{1 1}$

6. Aquatic-life criteria used to establish tier 1 classification for semi-volatile organic compounds in bed sediments 13

7. Concentration of trace elements and total organic carbon in bed sediment $\mathbf{1 5}$

8. Summary of bed-sediment data for semi-volatile organic compounds $\mathbf{1 8}$

9. Concentration of trace elements in quality-control samples $\mathbf{2 0}$

10. Concentration of semi-volatile organic compounds in quality-control samples 21

11. Ranking categories for trace elements in bed sediment 22

12. Sediment-quality scores and ranks for trace elements in bed sediment and percent land use or land cover of sampling sites 23

13. Ranking categories for semi-volatile organic compounds in bed sediment $\mathbf{2 4}$

14. Sediment-quality scores and ranks for semi-volatile organic compounds in bed sediment and percent land use or land cover of sampling sites $\mathbf{2 5}$

15. Sites exceeding sediment-quality guidelines for selected trace elements in bed sediment $\mathbf{2 7}$

16. Sites exceeding aquatic-life criteria for semi-volatile organic compounds in bed sediment 31 


\title{
CONVERSION FACTORS and ABBREVIATIONS AND ACRONYMS
}

Multiply

Inch (in.)

Feet $(\mathrm{ft})$

Mile (mi)

Square mile $\left(\mathrm{mi}^{2}\right)$
By

2.54

0.3048

1.609

2.590
To obtain

centimeters $(\mathrm{cm})$

meter $(\mathrm{m})$

kilometer $(\mathrm{km})$

square kilometer $\left(\mathrm{km}^{2}\right)$

Temperature is given in degrees Celsius $\left({ }^{\circ} \mathrm{C}\right)$ which can be converted to degrees Fahrenheit $\left({ }^{\circ} \mathrm{F}\right)$ by the following equation: ${ }^{\circ} \mathrm{F}=\left(1.8 \mathrm{x}^{\circ} \mathrm{C}\right)+32$

\author{
Abbreviations and Acronyms \\ $\mathrm{mg} / \mathrm{kg}$, milligram per kilogram \\ $\mathrm{mg} / \mathrm{L}$, milligram per liter \\ $\mu \mathrm{g} / \mathrm{g}$, micrograms per gram \\ $\mu \mathrm{g} / \mathrm{kg}$, microgram per kilogram \\ $\mu \mathrm{g} / \mathrm{L}$, microgram per liter \\ $\mu \mathrm{m}$, micrometer \\ $\mu \mathrm{S} / \mathrm{cm}$, microSiemens per centimeter \\ AET-H, apparent effects threshold-high \\ ER-M, effects range-median \\ FSV, factor summary value \\ GCMS, gas chromatography/mass spectroscopy \\ INRMP, Integrated Natural Resources Management Plan \\ MCL, maximum contaminant level \\ MRL, method reporting limit \\ MRLC, multi-resolution land characteristics \\ NWI, National Wetlands Inventory \\ OMOE, Ontario Ministry of the Environment \\ $\mathrm{PAH}$, polycyclic aromatic hydrocarbons \\ PEL, probable effects level \\ SAM, study area median \\ SECs, sediment effect concentrations \\ SQAL, sediment-quality advisory level \\ SQC, sediment-quality criterion \\ SQS, sediment quality score \\ SVOC, semi-volatile organic compound \\ TOC, total organic carbon \\ USEPA, U.S. Environmental Protection Agency \\ USGS, U.S.Geological Survey
}




\title{
TRACE ELEMENTS AND SEMI-VOLATILE ORGANIC COMPOUNDS IN
}

\author{
BED SEDIMENTS FROM STREAMS AND IMPOUNDMENTS
}

\section{AT FORT GORDON, GEORGIA}

By James B. McConnell, Timothy C. Stamey,

Howard H. Persinger Jr., and Keith W. McFadden

\begin{abstract}
In May 1998, the U.S. Geological Survey, in cooperation with the Environmental and Natural Resources Management Office of the U.S. Army Signal Center and Fort Gordon, investigated the presence and disbursal of trace elements and semi-volatile organic compounds in bed sediments from selected streams and impoundments at the Fort Gordon military installation near Augusta, Georgia. Concentrations of 18 trace elements and total organic carbon, and 66 semi-volatile compounds were determined from analysis of the fine-grained fraction of bed-sediment samples from 29 surface-water deposition sites.

Analysis of the bed-sediment data indicates that commercial and industrial land-use areas generally are associated with the highest concentrations of trace elements and semi-volatile organic compounds, and the greatest occurrence and distribution of trace elements and semi-volatile organic compounds in bed sediments at Fort Gordon. Bed sediment collected at sites having drainage areas less than 1.0 square mile and greater than 45 percent commercial and industrial land uses, have the most occurrences and the highest concentrations of trace elements and semi-volatile organic compounds. Sampling sites having less than 2 percent commercial and industrial land uses have the lowest concentrations, regardless of drainage basin size. Relative rankings and evaluation of individual trace element and semi-volatile organic compound concentration data identifies two sites that have substantially higher sediment-quality scores than the other sites. This suggests that these sites have the greatest potential risk for adverse effects on aquatic life. The effects of these elevated trace element and semi-volatile organic compound concentrations on aquatic life in these basins may merit further investigation.
\end{abstract}




\section{INTRODUCTION}

The U.S. Department of the Army (Army) uses water-quality information related to stormwater pollution prevention to support development of an Integrated Natural Resources Management Plan (INRMP) for Fort Gordon, $\mathrm{Ga}$. An effective INRMP ensures that natural resource conservation measures and Army activities on the military base are integrated and consistent with Federal requirements to manage installations on an ecosystem basis. Information on the occurrence and distribution of toxic substances in surface water on the base is needed to develop an INRMP at Fort Gordon. Toxic substances, when transported from source areas and deposited in streams may adversely affect aquatic life and stream ecosystems.

In May 1998, the U.S. Geological Survey (USGS), in cooperation with the Environmental and Natural Resources Management Office of the U.S. Army Signal Center and Fort Gordon, conducted a spatial survey of streams and impoundments to identify trace elements and semi-volatile organic compounds (SVOCs) associated with bed sediment in surface water at Fort Gordon. Trace elements and SVOCs (a class of industrially derived organic compounds) have low solubility in natural waters and tend to accumulate on silt- and clay-sized particles and organic matter. Point and nonpoint anthropogenic sources of trace elements include atmospheric deposition, urban and industrial wastes, urban runoff, storm sewers, landfills, vehicle maintenance areas, and agricultural and silvicultural activities. Although SVOCs may have similar sources as trace elements, specific sources of SVOCs are industrial areas, which use solvents, lubricants, oil additives, and combustion residues that enter surface water primarily in industrial and municipal wastewater effluent and in nonpoint-source runoff (Scudder and others, 1997). The majority of nonpoint-source contributions of trace elements and SVOCs likely are intermittent or related to storm events. As a result, the contaminants may not be detected in water samples collected randomly or even systematically. However, bed sediments in depositional environments of stream systems provide an integrated repository of particulate matter transported by a stream. Thus, a spatial survey of bed sediment can identify locations, potential source areas, and distributions of trace elements and SVOCs in surface water.

\section{Purpose and Scope}

This report describes the occurrence and distribution of trace elements and SVOCs in bed sediment at Fort Gordon, evaluates the association between bed-sediment quality and land use, and identifies potential source areas of contaminants and sites where bed-sediment quality can indicate an increased potential for adverse effects on aquatic life. The report contains concentration data for trace elements and SVOCs in bed-sediment samples at 29 sites collected from free-flowing and impounded segments of streams at Fort Gordon. A relative ranking of bedsediment-quality conditions at sampling sites in the study area and their relation to land-use activities in the watersheds are presented. Concentrations of trace elements and SVOCs are compared to reference site sedimentquality conditions and to available sediment-quality criteria to identify where trace elements and SVOCs may pose risks to aquatic life; and thus, may merit further investigation.

\section{Previous Investigations}

The U.S. Department of Agriculture, Natural Resources Conservation Service; and The University of Georgia, Environmental and Agricultural Engineering Department, evaluated water-quality conditions at six sites in 1995 to provide data for development of a comprehensive water-quality plan for Fort Gordon (Fort Gordon Water Quality Evaluation, written commun., 1995). No other information on any previous studies of water quality on Fort Gordon was located. 


\section{Description of Study Area}

Fort Gordon is located in east-central Georgia about 8 miles southwest of Augusta in Columbia, McDuffie, and Richmond Counties (fig. 1). The post, established in 1941 as Camp Gordon, became Fort Gordon in 1956 after being designated as a permanent military installation. The study area encompasses about 85 square miles ( $\mathrm{mi}^{2}$ ), and is generally defined by the boundary of the military reservation (one sampling site is located just outside the boundary).

Fort Gordon lies in the northern part of the Coastal Plain Province in Georgia, near the Fall Line (fig. 1). The Fall Line marks the boundary between Coastal Plain sediments and crystalline rocks of the Piedmont Province. Relief in the Coastal Plain Province generally is greatest near the Fall Line and decreases in a southeasterly direction. Rolling hills and well-developed dendritic stream patterns characterize the topography at Fort Gordon. Altitudes range from about 540 feet ( $\mathrm{ft}$ ) above sea level along the northern boundary of the military reservation to $250 \mathrm{ft}$ along the southern boundary.

Military activities at Fort Gordon have included division training for Infantry and Armored Divisions, Southeastern Signal School, Military Police, and anti-aircraft Artillery Brigade operations. After the Vietnam War, the Army consolidated the majority of the communications training at Fort Gordon. In 1974, Fort Gordon was designated as the United States Army Signal Center. Currently, Fort Gordon is one of the largest communicationselectronic facilities in the world.

General land use in the western part of the fort consists of upland areas that typically are forested and contain wetlands and some small impoundments. The eastern part of Fort Gordon is more developed with industrial and military-related operation facilities.

Soils generally consist of well-sorted, unconsolidated sands that are highly erodable. Sand particle sizes are highly variable, but are generally medium grained and poorly sorted, and are present in layers up to $20 \mathrm{ft}$ thick. Areas of flattened and rounded fine gravel typically are present near the base of the sand layers. Locally, lenses of silty to sandy clay ranging in thickness from 1 to $3 \mathrm{ft}$ are present (Fort Gordon Environmental and Natural Resources Office, written commun., 1998).

\section{Study Design}

Bed-sediment samples were collected at 29 sites selected to evaluate contaminant contributions from selected drainage basins on Fort Gordon (fig. 1, table 1). Sampling was conducted during a sustained period of low baseflow in May 1998.

Potential contaminant sources in these basins include motor pools and maintenance facility operations, personnel training and testing areas, closed landfills, vehicle wash areas, and weapons impact areas. For the purpose of data comparison, two reference sites also were selected near stream headwaters, which have minimal land disturbance and are primarily forested. Sample sites consisted of seven impounded stream reaches (sites 1, 2, 3, 9, 10, 24 and 27); two stream reaches upstream of breached dams (sites 19 and 21); two ponds formed by beaver dams (sites 4 and 12); a partially dry pond (site 17); a stream segment directly below the outflow from a closed landfill (site 16); and segments in 16 unregulated streams. Field measurements of water temperature, specific conductance, $\mathrm{pH}$, dissolved-oxygen concentration, and dissolved-oxygen saturation provided data on the general water-quality condition of streams at the time of bed-sediment sampling. 


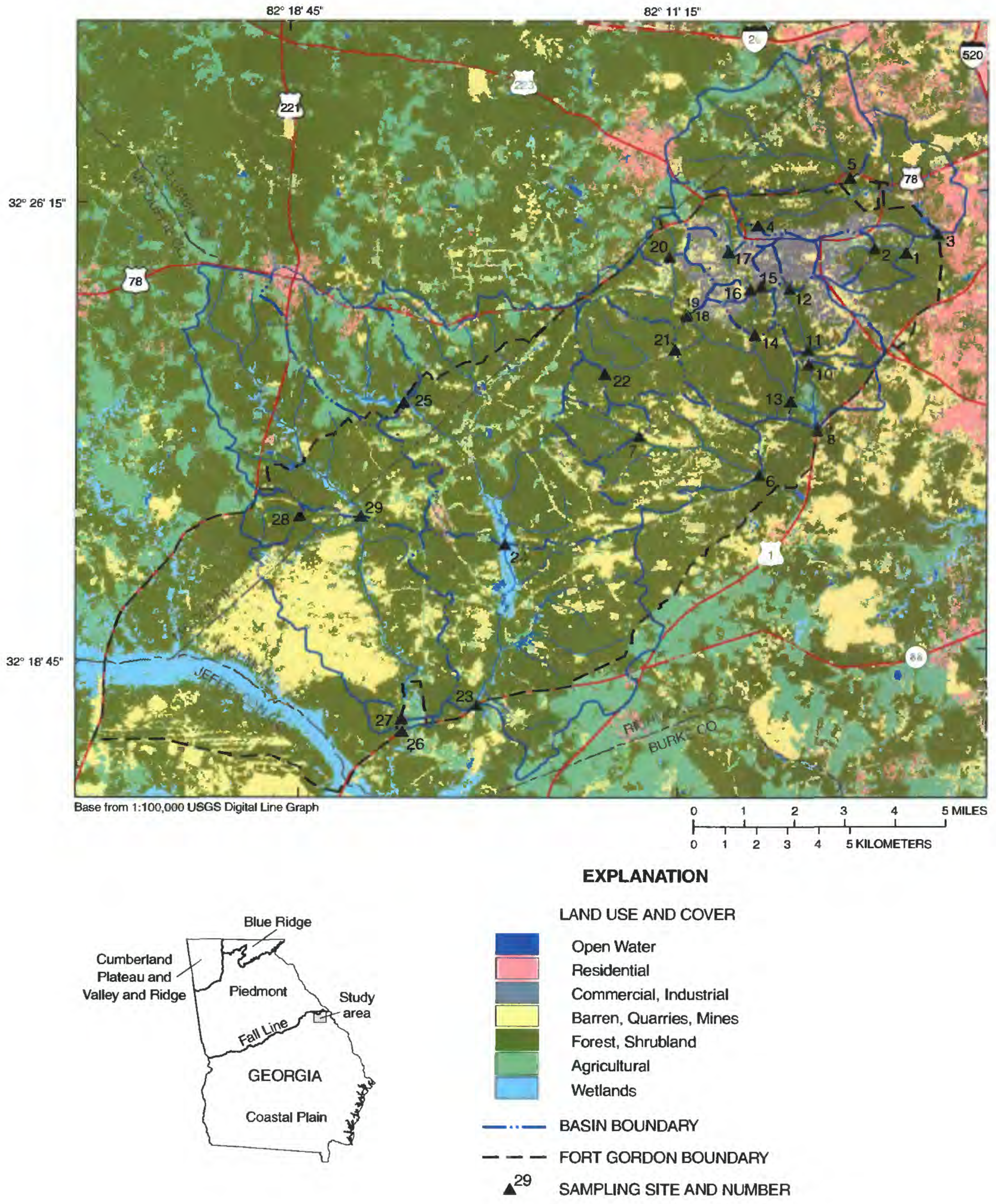

Figure 1. Bed-sediment sampling sites, drainage areas, and land use in Fort Gordon, Georgia, study area. 
Table 1. Site information for bed-sediment sampling sites, Fort Gordon, Georgia

[Latitude and longitude are in degrees, minutes, and seconds]

\begin{tabular}{|c|c|c|c|c|}
\hline $\begin{array}{c}\text { Site } \\
\text { number } \\
\text { (figs. 1-4) }\end{array}$ & $\begin{array}{l}\text { Station } \\
\text { number }\end{array}$ & Latitude & Longitude & Site name \\
\hline \multicolumn{5}{|c|}{ Butler Creek drainage basin } \\
\hline 1 & 02196843 & $33^{\circ} 25^{\prime} 15^{\prime \prime}$ & $82^{\circ} 06^{\prime} 35^{\prime \prime}$ & Butler Creek tributary above Boardmans Pond \\
\hline 2 & 02196842 & $33^{\circ} 25^{\prime} 20^{\prime \prime}$ & $82^{\circ} 07^{\prime} 13^{\prime \prime}$ & Soil Erosion Lake \\
\hline 3 & 02193838 & $33^{\circ} 25^{\prime} 33^{\prime \prime}$ & $82^{\circ} 05^{\prime} 57^{\prime \prime}$ & Butler Creek Reservoir \\
\hline 4 & 02196823 & $33^{\circ} 25^{\prime} 44^{\prime \prime}$ & $82^{\circ} 09^{\prime} 32^{\prime \prime}$ & Butler Creek tributary (beaver pond) \\
\hline 5 & 02196821 & $33^{\circ} 26^{\prime} 29^{\prime \prime}$ & $82^{\circ} 07^{\prime} 41^{\prime \prime}$ & Butler Creek at U.S. Highway 78 \\
\hline \multicolumn{5}{|c|}{ South Prong Creek drainage basin } \\
\hline 6 & 02197023 & $33^{\circ} 21^{\prime} 39^{\prime \prime}$ & $82^{\circ} 09^{\prime} 34^{\prime \prime}$ & South Prong Creek above Ellis Pond \\
\hline 7 & 02197022 & $33^{\circ} 22^{\prime} 19^{\prime \prime}$ & $82^{\circ} 11^{\prime} 56^{\prime \prime}$ & South Prong Creek near headwaters \\
\hline \multicolumn{5}{|c|}{ Spirit Creek drainage basin } \\
\hline 8 & 02197020 & $33^{\circ} 22^{\prime} 23^{\prime \prime}$ & $82^{\circ} 08^{\prime} 23^{\prime \prime}$ & Spirit Creek at U.S. Highway 1 \\
\hline 9 & 021970190 & $33^{\circ} 22^{\prime} 24^{\prime \prime}$ & $82^{\circ} 08^{\prime} 23^{\prime \prime}$ & Gordon Lake \\
\hline 10 & 021970180 & $33^{\circ} 23^{\prime} 27^{\prime \prime}$ & $82^{\circ} 08^{\prime} 33^{\prime \prime}$ & Mirror Lake \\
\hline 11 & 021970175 & $33^{\circ} 23^{\prime} 41^{\prime \prime}$ & $82^{\circ} 08^{\prime} 34^{\prime \prime}$ & Spirit Creek tributary above Mirror Lake \\
\hline 12 & 021970168 & $33^{\circ} 24^{\prime} 41^{\prime \prime}$ & $82^{\circ} 08^{\prime} 55^{\prime \prime}$ & Spirit Creek tributary near headwaters \\
\hline 13 & 021970165 & $33^{\circ} 22^{\prime} 51^{\prime \prime}$ & $82^{\circ} 08^{\prime} 55^{\prime \prime}$ & Spirit Creek above Gordon Lake \\
\hline 14 & 021970158 & $33^{\circ} 23^{\prime} 56^{\prime \prime}$ & $82^{\circ} 09^{\prime} 37^{\prime \prime}$ & McCoy Creek below Signal Lake \\
\hline 15 & 021970150 & $33^{\circ} 24^{\prime} 44^{\prime \prime}$ & $82^{\circ} 09^{\prime} 29^{\prime \prime}$ & McCoy Creek tributary at Range Road \\
\hline 16 & 021970146 & $33^{\circ} 24^{\prime} 41^{\prime \prime}$ & $82^{\circ} 09^{\prime} 42^{\prime \prime}$ & $17^{\text {th }}$ Street Landfill drainage \\
\hline 17 & 021970140 & $33^{\circ} 25^{\prime} 18^{\prime \prime}$ & $82^{\circ} 10^{\prime} 07^{\prime \prime}$ & McCoy Creek above Signal Lake \\
\hline 18 & 021970136 & $32^{\circ} 24^{\prime} 15^{\prime \prime}$ & $82^{\circ} 10^{\prime} 59^{\prime \prime}$ & Marcum Branch below Maxwell dam \\
\hline 19 & 021970135 & $32^{\circ} 24^{\prime} 17^{\prime \prime}$ & $82^{\circ} 11^{\prime} 00^{\prime \prime}$ & Marcum Branch above Maxwell dam \\
\hline 20 & 021970130 & $33^{\circ} 25^{\prime} 14^{\prime \prime}$ & $82^{\circ} 11^{\prime} 18^{\prime \prime}$ & North Fork Spirit Creek \\
\hline 21 & 021970128 & $33^{\circ} 23^{\prime} 43^{\prime \prime}$ & $82^{\circ} 11^{\prime} 12^{\prime \prime}$ & Thomas Lake \\
\hline 22 & 021970120 & $33^{\circ} 23^{\prime} 20^{\prime \prime}$ & $82^{\circ} 12^{\prime} 36^{\prime \prime}$ & Middle Fork Spirit Creek (headwaters) \\
\hline \multicolumn{5}{|c|}{ Sandy Run Creek drainage basin } \\
\hline 23 & 02197560 & $33^{\circ} 17^{\prime} 56^{\prime \prime}$ & $82^{\circ} 15^{\prime} 13^{\prime \prime}$ & Sandy Run Creek at U.S. Highway $1 /$ State Route 4 \\
\hline 24 & 021975593 & $33^{\circ} 20^{\prime} 33^{\prime \prime}$ & $82^{\circ} 14^{\prime} 37^{\prime \prime}$ & Lower Leitner Lake \\
\hline 25 & 021975590 & $33^{\circ} 22^{\prime} 55^{\prime \prime}$ & $82^{\circ} 16^{\prime} 35^{\prime \prime}$ & Sandy Run Creek above Fort Gordon \\
\hline \multicolumn{5}{|c|}{ Boggy Gut Creek drainage basin } \\
\hline 26 & 021975588 & $33^{\circ} 17^{\prime} 31^{\prime \prime}$ & $82^{\circ} 16^{\prime} 41^{\prime \prime}$ & Boggy Gut Creek below Claussen Pond \\
\hline 27 & 021975587 & $33^{\circ} 17^{\prime} 43^{\prime \prime}$ & $82^{\circ} 16^{\prime} 42^{\prime \prime}$ & George Claussen Pond \\
\hline 28 & 021975582 & $33^{\circ} 21^{\prime} 04^{\prime \prime}$ & $82^{\circ} 18^{\prime} 40^{\prime \prime}$ & Boggy Gut Creek tributary (headwaters) \\
\hline 29 & 021975584 & $33^{\circ} 21^{\prime} 03^{\prime \prime}$ & $82^{\circ} 17^{\prime} 27^{\prime \prime}$ & Boggy Gut Creek near county lines \\
\hline
\end{tabular}




\section{General Water-Quality Condition of Streams}

A calibrated multi-parameter field instrument was used at each site to measure water temperature, specific conductance, $\mathrm{pH}$, dissolved-oxygen concentration, and dissolved-oxygen saturation during the collection of the bedsediment samples (table 2). Field measurements at the lake and pond sites were taken about $3 \mathrm{ft}$ below the water surface. These measurements may be indicative of general stream-quality conditions during the sampling period of sustained base streamflow in May 1998. Water temperature at the sites ranged from 18.0 degrees Celsius $\left({ }^{\circ} \mathrm{C}\right)$ at site 4 to $28.0^{\circ} \mathrm{C}$ at sites 8 and 9 . The highest water temperatures generally occurred at sites in or directly downstream from impounded water. Specific conductance generally was low in most streams indicating waters of low dissolved-solids content. Specific conductance at 28 of the 29 sites ranged from 13 to 60 microSiemens per centimeter at $25^{\circ} \mathrm{C}(\mu \mathrm{S} / \mathrm{cm})$ with values less than $25 \mu \mathrm{S} / \mathrm{cm}$ at nearly half the sites. The exception $(960 \mu \mathrm{S} / \mathrm{cm})$ occurred at site 16, directly downstream from a closed landfill.

Measurements of $\mathrm{pH}$ indicated that most streams at Fort Gordon were slightly acidic during the samplecollection period, having $\mathrm{pH}$ values less than 7.0 (neutral). Water of low $\mathrm{pH}$ occurs naturally in streams at Fort Gordon, and is attributed in part to dilute, poorly buffered waters draining forested basins. $\mathrm{pH}$ values less than 6.0, were measured at 15 of the 29 sites. For streams supporting warm-water species of fish, $\mathrm{pH}$ of 6.0 is the threshold used by Georgia Department of Natural Resources aquatic-life criteria (Georgia Department of Natural Resources, 1998). $\mathrm{pH}$ values less than 5.0 were measured at three sites $(7,21$, and 22) (fig. 1, table 2). The highest pH value of about 7.5 (slightly basic), and the only $\mathrm{pH}$ above 7.0 was measured at site 9 (fig. 1, table 2). Apparently phytoplankton productivity in the lake, as indicated by a dissolved-oxygen concentration well above the saturation level (142 percent) (table 2), resulted in photosynthetic utilization of carbon dioxide that caused slightly basic lake waters.

Dissolved-oxygen concentrations at 26 of the 29 stream sites exceeded the Georgia water-quality standard (daily average of 5 milligrams per liter ( $\mathrm{mg} / \mathrm{L}$ ) but not less than $4 \mathrm{mg} / \mathrm{L}$ at any time) for waters supporting warmwater species of fish (Georgia Department of Natural Resources, 1998). Concentrations less than $4 \mathrm{mg} / \mathrm{L}$ occurred at sites $4(2.1 \mathrm{mg} / \mathrm{L}), 21(3.0 \mathrm{mg} / \mathrm{L})$, and $25(4.6 \mathrm{mg} / \mathrm{L})$. The probable cause for low dissolved-oxygen concentrations at sites 4 and 21 is oxygen demand by bottom sediments in these shallow and nearly stagnant water sites. The cause of low dissolved-oxygen concentrations at site 25 is not known (fig.1, table 2). 
Table 2. Water-quality field data collected at bed-sediment sampling sites

$\left[{ }^{\circ} \mathrm{C}\right.$, degrees Celsius; $\mu \mathrm{S} / \mathrm{cm}$, microSiemens per centimeter; $\mathrm{mg} / \mathrm{L}$, milligrams per liter; - , no measurement]

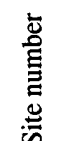

$\begin{array}{cccc} & & \text { Water } & \text { Specific } \\ \text { temperature } & \text { conductance } \\ \text { Site name } & \text { Sample } & \left({ }^{\circ} \mathrm{C}\right) & (\mu \mathrm{S} / \mathrm{cm} \\ & & \left.\text { at } 25^{\circ} \mathrm{C}\right)\end{array}$

\begin{tabular}{|c|c|c|}
\hline$\underset{\text { (units }}{\mathrm{pH}}$ & $\begin{array}{c}\text { Dissolved } \\
\text { oxygen } \\
\text { (mg/L) }\end{array}$ & $\begin{array}{l}\text { Dissolved } \\
\text { oxygen } \\
\text { saturation } \\
\text { (percent) }\end{array}$ \\
\hline
\end{tabular}

1 Butler Creek tributary above

Butler Creek drainage basin

Boardmans Pond

Soil Erosion Lake

Butler Creek Reservoir

Butler Creek tributary (beaver pond)

Butler Creek at U.S. Highway 78

05/13/98

$19.7 \quad 25$

$05 / 14 / 98$

21.3

43

$05 / 14 / 98$

24.3

43

28

18.0

59

$05 / 13 / 98$

18.3

31

$(\mathrm{mg} / \mathrm{L})$

(percent)

South Prong Creek drainage basin

South Prong Creek above Ellis Pond

7 South Prong Creek near headwaters

$05 / 13 / 98$

$05 / 28 / 98$

$\begin{array}{ll}26.2 & 13 \\ 23.5 & 15\end{array}$

15

Spirit Creek drainage basin

$\begin{array}{lll}05 / 27 / 98 & 28.0 & 55 \\ 05 / 28 / 98 & 28.0 & 54 \\ 05 / 14 / 98 & 23.0 & 27 \\ 05 / 12 / 98 & 18.8 & 34\end{array}$

$05 / 13 / 98$

$05 / 12 / 98$

$05 / 12 / 98$

$05 / 12 / 98$

$05 / 27 / 98$

$05 / 12 / 98$

$05 / 12 / 98$

$05 / 12 / 98$

$05 / 13 / 98$

$05 / 28 / 98$

$05 / 28 / 98$

$$
22.0
$$

$$
20.5
$$

45

20.1

20.3

19.9

60

20.4

22.0

22.0

19.9

26.0

20.5

55
54
27
34

25

45
60
40
960
22
16
16
22
22
24

Middle Fork Spirit Creek

(headwaters)

23 Sandy Run Creek at U.S. Highway

$1 /$ State Route 4

24 Lower Leitner Lake

25 Sandy Run Creek above Ft. Gordon

\begin{tabular}{ll}
26 & $\begin{array}{l}\text { Boggy Gut Creek below Claussen } \\
\text { Pond }\end{array}$ \\
27 & $\begin{array}{l}\text { George Claussen Pond } \\
28\end{array}$ \\
$\begin{array}{l}\text { Boggy Gut Creek } \\
\text { tributary(headwaters) }\end{array}$ \\
29 & Boggy Gut Creek near county lines \\
\hline
\end{tabular}

Sandy Run Creek drainage basin

$\begin{array}{lll}05 / 27 / 98 & 24.9 & 18 \\ 05 / 13 / 98 & 23.0 & 21 \\ 05 / 15 / 98 & 24.2 & 29\end{array}$

Boggy Gut Creek drainage basin

\begin{tabular}{llllll}
$05 / 27 / 98$ & 26.4 & 14 & 5.72 & 5.9 & 74 \\
$05 / 14 / 98$ & 22.0 & 14 & 5.19 & 7.8 & 89 \\
$05 / 15 / 98$ & 20.2 & 22 & 5.22 & - & - \\
$05 / 15 / 98$ & 21.0 & 19 & 5.37 & 5.2 & 60 \\
\hline
\end{tabular}

87

106

55

74

89

60

\section{9}

103

81

22

86

100

65

$\begin{array}{ll}5.82 & 5.2\end{array}$

$\begin{array}{lrr}6.47 & 6.7 & 87\end{array}$

$\begin{array}{lll}7.48 & 11.0 & 142\end{array}$

$\begin{array}{lll}6.19 & 5.2 & 61\end{array}$

$\begin{array}{lll}6.51 & 7.9 & 86\end{array}$

$6.10-$

$\begin{array}{lll}6.15 & 7.6 & 85\end{array}$

$\begin{array}{lll}6.63 & 7.7 & 86\end{array}$

$\begin{array}{lll}5.84 & 6.7 & 75\end{array}$

$\begin{array}{lll}6.40 & 5.4 & 67\end{array}$

$\begin{array}{lll}5.46 & 6.9 & 77\end{array}$

$\begin{array}{lll}5.67 & 7.2 & 81\end{array}$

$\begin{array}{lll}5.67 & 7.2 & 81\end{array}$

$\begin{array}{lll}6.00 & 7.9 & 88\end{array}$

$\begin{array}{lll}4.51 & 3.0 & 37\end{array}$

$\begin{array}{lll}4.32 & 5.2 & 58\end{array}$

58 


\section{METHODS OF INVESTIGATION}

The methods described in the following sections were used to evaluate the risks of contamination of sensitive waterbodies such as, lakes, wetlands, and other ponded waters that accumulate fine-grain bed sediments and associated trace elements and hydrophobic organic compounds (semi-volatile organic compounds). Discussed in this section are methods for data collection, quality-control samples, drainage-area basin characterization, data analysis, and aquatic-life criteria.

\section{Basin Characterization}

The drainage-area boundaries for the 29 sites were delineated by interpreting topographic characteristics (contours, elevations, drainage patterns) from the most recent 1:24,000-scale USGS 7.5 quadrangle topographic maps (1957-1980). Land use and land cover of the drainage areas upstream of the sampled sites were derived from the Multi-Resolution Land Characteristics (MRLC) digital data set and reclassified into seven classifications; forest and shrubland, barren, commercial and industrial, residential, agricultural, wetlands, and open water (fig. 1, table 3). Estimates of percent land use and land cover for each classification within each drainage area were determined by dividing the sum of areas for each classification by the drainage area.

\section{Bed-Sediment Samples}

Trace element and SVOC bed-sediment samples at stream sites were collected from exposed and/or submerged depositional areas that contain fine-grained sediments. Generally, these samples were collected along a 150 to $200 \mathrm{ft}$ reach immediately upstream and downstream from locations shown in figure 1; these sites were wadable at the time of sampling. Samples were collected using a Teflon ${ }^{\mathrm{TM}}$ spatula to scoop the upper 1-2 centimeters $(\mathrm{cm})$ of fine-grained material from the bed deposits. Samples were composited in a clean baked-glass container until enough material was collected for chemical analysis. Trace element and SVOC bed-sediment samples at impounded sites were collected from a boat at 6 to 10 locations between the inflow(s) and dam using an Ekman dredge sampler. For each grab sample collected, the upper 6 to $10 \mathrm{~cm}$ of sediment was removed from the central part of the dredge with a Teflon ${ }^{\top M}$ scoop, being careful not to scrape the walls of the dredge, and composited into a clean baked-glass container.

Composite samples from each sampling site were processed by manually mixing the composite sample, then sieving through a 2-millimeter $(\mathrm{mm})$ stainless-steel mesh screen. Subsamples for analysis of SVOCs and trace elements were withdrawn from the sieved samples and placed in clean sample containers. SVOC samples were shipped on ice to the USGS National Water Quality Laboratory in Denver, Colo. Trace element samples were delivered to the USGS Sediment Partitioning Research Laboratory in Atlanta, Ga.

Trace element samples were prepared for chemical analysis in the Atlanta laboratory by freeze drying and then sieving through a 63-micrometer $(\mu)$ mesh screen. Aliquots from the prepared samples were digested in a strong acid mixture to completely solubilize the metals from the sediment matrix. The aliquots were analyzed for total trace element concentrations by a combination of atomic absorption and direct emission spectrometry methods (Horowitz and Elrick, 1987). SVOCs were extracted from the bed-material samples by solvent extraction in the laboratory, followed by partial isolation using high-performance gel permeation chromatography, then qualitatively identified and quantified by capillary-column gas chromatography/mass spectrometry (Furlong and others, 1996). 
Table 3. Drainage area and land-use or land-cover characteristics of sampling sites

$\left[\mathrm{mi}^{2}\right.$, square miles; Do., ditto; Note: Drainage areas determined from U.S. Geological Survey 7.5-minute quadrangle maps: August West (photorevised 1980); Avondale (1957); Blyth (photorevised 1971); Harlem (photorevised 1980). Primary data source for land-use and land-cover coverages in Landsat TM data sets, acquired from 1989-93]

\begin{tabular}{|c|c|c|c|c|c|c|c|c|c|}
\hline 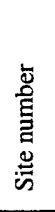 & 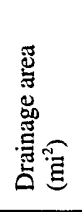 & 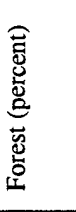 & 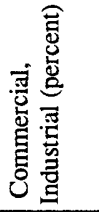 & 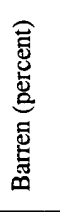 & 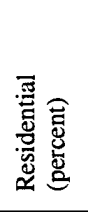 & 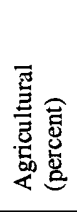 & 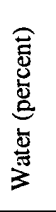 & 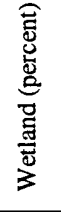 & $\begin{array}{l}\text { Description of land use and land cover in drainage area } \\
\text { upstream of sampling site }\end{array}$ \\
\hline 1 & 1.8 & 53.1 & 26.3 & 12.4 & 0.0 & 7.6 & 0.4 & 0.1 & $\begin{array}{l}\text { Mostly forested. Base housing, military facility buildings and parking areas along western rim of divide } \\
\text { Golf course along northeast rim of drainage area divide. Soil Erosion Lake about } 0.7 \mathrm{mi} \text { above site. }\end{array}$ \\
\hline 2 & 0.9 & 28.2 & 44.6 & 16.3 & 0.0 & 10.1 & 0.8 & 0.0 & $\begin{array}{l}\text { Military facility buildings and parking areas along western drainage area divide. Forested in lower part } \\
\text { of drainage area. Golf course along northeast rim of drainage area divide. }\end{array}$ \\
\hline 3 & 13.0 & 67.2 & 3.9 & 12.9 & 6.7 & 7.3 & 1.0 & 0.8 & $\begin{array}{l}\text { Mostly forested. Some mixed land use including agriculture, industry, suburban residential, wetlands, } \\
\text { roads and drainage, and small towns. Military facility buildings, parking, and motor pool service } \\
\text { area, wash/grease racks along part of southern drainage area divide. }\end{array}$ \\
\hline 4 & 0.2 & 30.9 & 57.1 & 11.1 & 0.0 & 2.3 & 0.0 & 0.0 & $\begin{array}{l}\text { Military facility buildings, roads and drainage, motor pool service area, wash/grease racks. Beaver dam } \\
\text { causes ponded water at site. }\end{array}$ \\
\hline 5 & 7.5 & 69.1 & 0.6 & 12.0 & 5.7 & 11.6 & 0.2 & 0.7 & $\begin{array}{l}\text { Mostly forested. Some mixed land use including agriculture, industry, suburban residential, wetlands, } \\
\text { roads and drainage, and small towns. Military facility buildings, parking, and motor pool service } \\
\text { area, wash/grease racks along southern edge of drainage area divide. }\end{array}$ \\
\hline 6 & 5.9 & 76.8 & 0.4 & 20.4 & 0.0 & 2.0 & 0.0 & 0.4 & Forested and open land, small arms impact area along western ridge of drainage area divide. \\
\hline 7 & 1.3 & 88.4 & 0.1 & 9.3 & 0.0 & 2.0 & 0.1 & 0.3 & Forested, small arms impact area along western ridge of drainage area divide. \\
\hline 8 & 17.5 & 88.4 & 0.1 & 9.3 & 0.0 & 2.0 & 0.1 & 0.3 & $\begin{array}{l}\text { Mostly forested. Other land use includes roads and drainage, sewage treatment facility, closed land-fills } \\
\text { small arms impact area, motor pools, vehicle wash area, residential housing. Drainage area contains } \\
\text { most of the military facility buildings located along the northern drainage area divide.. }\end{array}$ \\
\hline 9 & 17.5 & 66.1 & 13.5 & 14.1 & 0.4 & 5.3 & 0.3 & 0.4 & $\begin{array}{l}\text { Mixed land use including roads and drainage, sewage treatment facility, abandoned landfills, small arm } \\
\text { impact area, motor pools, vehicle wash area, residential housing. Drainage area contains most of the } \\
\text { military facility buildings that are located along the northern drainage area divide. }\end{array}$ \\
\hline 10 & 3.0 & 43.3 & 31.9 & 20.3 & 0.0 & 3.8 & 0.3 & 0.3 & $\begin{array}{l}\text { Mixed land use, forested stream riparian area, military facility buildings along the northern drainage } \\
\text { area divide, roads and drainage, two closed landfills, residential housing. }\end{array}$ \\
\hline 11 & 2.2 & 37.4 & 40.4 & 17.7 & 0.0 & 4.1 & 0.0 & 0.2 & Do. \\
\hline 12 & 0.6 & 5.7 & 13.1 & 76.9 & 0.0 & 4.4 & 0.0 & 0.0 & $\begin{array}{l}\text { Mostly military facility complex. Military facility buildings along the northern drainage area divide, } \\
\text { roads and drainage, two abandoned landfills. }\end{array}$ \\
\hline 13 & 13.0 & 71.3 & 12.5 & 10.9 & 0.0 & 4.9 & 0.1 & 0.3 & $\begin{array}{l}\text { Mixed land use; drainage area contains most of the military building complex located along northern } \\
\text { drainage area divide, roads and drainage, sewage treatment facility, abandoned landfills, small arms } \\
\text { impact area, motor pools, vehicle wash area, residential housing. }\end{array}$ \\
\hline 14 & 3.2 & 35.2 & 20.8 & 32.2 & 0.0 & 11.5 & 0.0 & 0.5 & $\begin{array}{l}\text { Mixed land use; wooded stream riparian area, military buildings mostly along western part of drainage } \\
\text { area, abandoned landfill, motor pools, vehicle wash area. }\end{array}$ \\
\hline 15 & 0.3 & 10.2 & 14.9 & 67.8 & 0.0 & 6.6 & 0.0 & 0.0 & $\begin{array}{l}\text { Military facility buildings, roads and drainage in upper half of drainage area. Forested stream riparian } \\
\text { area in lower part of drainage area. }\end{array}$ \\
\hline 16 & 0.2 & 7.2 & 48.5 & 36.3 & 0.0 & 7.8 & 0.0 & 0.0 & $\begin{array}{l}\text { Assorted military buildings in upper part of drainage area, abandoned landfill in lower part of drainage } \\
\text { area. Open, natural areas. Flow consists of water discharged from culvert pipe in landfill. }\end{array}$ \\
\hline 17 & 1.0 & 46.8 & 16.3 & 32.4 & 0.0 & 4.0 & 0.0 & 0.5 & $\begin{array}{l}\text { Mostly forested. Military facility buildings along southwestern part of drainage area divide, oil storage } \\
\text { facility. }\end{array}$ \\
\hline 18 & 2.8 & 66.6 & 17.0 & 8.9 & 0.2 & 6.9 & 0.0 & 0.3 & $\begin{array}{l}\text { Mostly forested. Military facility buildings along eastern edge of drainage area divide, ammunition } \\
\text { storage area. }\end{array}$ \\
\hline 19 & 2.8 & 66.6 & 17.0 & 8.9 & 0.2 & 6.9 & 0.0 & 0.3 & Do. \\
\hline 20 & 0.6 & 67.8 & 13.9 & 6.0 & 0.0 & 11.9 & 0.0 & 0.4 & $\begin{array}{l}\text { Mostly forested. A few military facility buildings and railroad tracks along eastern edge of drainage are } \\
\text { divide. US } 278 \text { crosses upper northwest part of drainage area. }\end{array}$ \\
\hline 21 & 3.3 & 60.0 & 17.4 & 10.6 & 0.2 & 11.5 & 0.0 & 0.3 & Forested. Artillery impact area. \\
\hline 22 & 0.5 & 88.8 & 9.5 & 0.1 & 0.0 & 1.2 & 0.0 & 0.3 & Forested headwaters. \\
\hline 23 & 32.6 & 69.2 & 11.5 & 0.6 & 1.3 & 13.2 & 1.0 & 3.2 & $\begin{array}{l}\text { Mixed land use. Mostly forested and open, natural areas. Rural, small farm agriculture, town of Harlem } \\
\text { in headwaters. Low-use military reservation area. }\end{array}$ \\
\hline 24 & 19.7 & 69.0 & 10.1 & 0.8 & 2.0 & 14.0 & 1.1 & 3.0 & Do. \\
\hline 25 & 4.7 & 58.6 & 1.9 & 2.0 & 6.3 & 25.6 & 0.8 & 4.6 & $\begin{array}{l}\text { Mixed land use. Mostly forested and open areas along ridge tops, town of Harlem in headwaters. } \\
\text { Numerous lakes and ponds. }\end{array}$ \\
\hline 26 & 21.7 & 64.2 & 21.7 & 0.1 & 0.4 & 9.6 & 0.2 & 3.8 & $\begin{array}{l}\text { Mostly forested and open areas. Small farm agriculture along ridge tops. Artillery impact area in } \\
\text { western part of drainage area. }\end{array}$ \\
\hline 27 & 21.3 & 64.0 & 22.0 & 0.0 & 0.4 & 9.5 & 0.2 & 3.8 & Do. \\
\hline 28 & 0.9 & 89.4 & 5.3 & 0.0 & 0.0 & 3.0 & 0.0 & 2.1 & Mostly forested. Open areas along ridge tops. \\
\hline 29 & 10.8 & 73.1 & 5.5 & 0.1 & 0.7 & 16.3 & 0.5 & 3.9 & Do. \\
\hline
\end{tabular}




\section{Bed-Sediment Quality-Control Samples}

Quality-control samples were collected at Fort Gordon to provide information on variability and possible bias of constituent concentrations resulting from sample collection, processing, and analytical procedures. Qualitycontrol samples consisted of a regular and duplicate sample collected at site 24 (fig. 1) and a sample split from the regular and duplicate sample. The regular and duplicate samples were collected sequentially as separate grab samples at 6 to 10 locations within the lake and composited in separate, clean glass containers. Each sample was manually mixed, then sieved through a 2-mm stainless-steel mesh screen and placed in clean sample containers. In addition, a subsample (split) was taken from the regular and duplicate samples.

Bed-sediment quality-control samples were analyzed in the laboratories for trace elements and SVOCs. The analysis of the quality-assurance samples indicated no unusual variability or bias in the sample sets.

\section{Bed-Sediment Data-Analysis Methods}

Bed-sediment-quality characteristics for trace elements and SVOCs were evaluated using the relative ranking system similar to that described by Gilliom and others (1998). Data used in the evaluation consisted of analysis of composited bed-material samples collected in May 1998 at 29 sites. Factors (constituents) were selected for each characteristic and grouped to define that characteristic. The purpose of grouping is to simplify computations and reduce problems associated with nondetections and high variability in the samples. This procedure allows a uniform assessment for sediment-quality characteristics (Gilliom and others, 1998). Bed-sediment-quality characteristics and factors are listed in table 4.

Table 4. Bed-sediment-quality characteristics and associated factors used to develop relative rankings of bed sediment

\begin{tabular}{|c|c|c|}
\hline $\begin{array}{l}\text { Bed-sediment quality } \\
\text { characteristic }\end{array}$ & $\begin{array}{c}\text { Number } \\
\text { of } \\
\text { factors }\end{array}$ & $\begin{array}{l}\text { Factors that define } \\
\text { the characteristics }\end{array}$ \\
\hline Trace elements & ${ }^{1 / 14}$ & $\begin{array}{l}\text { Total concentrations of antimony, arsenic, barium, berylium, } \\
\text { cadmium, chromium, cobalt, copper, lead, mercury, nickel, } \\
\text { selenium, vanadium, and zinc }\end{array}$ \\
\hline $\begin{array}{l}\text { Semi-volatile organic } \\
\text { compounds }\end{array}$ & ${ }^{2 / 4} 4$ & $\begin{array}{l}\text { Total concentrations of polycyclic aromatic hydrocarbons, } \\
\text { phenols, phthalates, and other SVOCs }\end{array}$ \\
\hline
\end{tabular}

${ }^{1 /}$ For trace elements that relate to individual elements.

${ }^{2 /}$ Classes of compounds.

Sediment-quality scores were calculated from the bed-sediment data, grouped by quartiles, and the quartiles then assigned a rank from 1 (best) to 4 (worst). Sediment-quality scores were computed according to:

$$
\begin{aligned}
& S Q S_{i}=\frac{\sum_{f=1}^{n_{i}} \frac{F S V_{1}}{S A M_{f}}}{n_{i}} \\
& \text { where } \\
& S Q S_{i}=\text { sediment-quality score for characteristic } i, \\
& n_{i}=\text { number of factors } f \text { in characteristic } i, \\
& F S V_{1}=\text { factor summary value for factor } f \\
& S A M_{f}=\text { study area median of } F S V_{1} \text { for all stream sites. }
\end{aligned}
$$


Because the sediment-quality score for sites is based only on one sample per site, the factor summary value (FSV) for trace elements at each site is simply the value determined by the analysis. The FSV for SVOCs at each site is the sum of the detected concentrations for each factor. Computations of sediment-quality scores for trace elements and SVOCs are discussed further in the "Relative Ranking of Bed-Sediment Quality" section of this report.

\section{Identification of Reference Sites}

Reference site bed-sediment-quality conditions are useful benchmarks for comparison with other observed site concentrations to identify drainage areas upstream from the sampled sites that have potential source areas of contaminants. For this study, specific reference sites were selected that were located away from presumed potential sources of contaminants. The reference site sediment-quality conditions for trace elements and SVOCs in the study area are represented by concentrations in samples from 2 sites $(22,28)$ (table 3 , fig. 1). Methods of using traceelement data associated with fine-grained sediments and lake bed-sediment data that represent sediment-quality conditions in the Great Lakes basins (Persuad and others, 1993) were incorporated for comparisons of observed data from a range of typical reference site concentrations. These methods were used only as guideline procedures for screening and categorizing the concentration data.

\section{Aquatic-Life Criteria for Bed Sediment}

Aquatic-life criteria for trace elements in bed sediment collected in surface water at Fort Gordon were evaluated using sediment-quality methodologies and guidelines developed by Ontario Ministry of the Environment (OMOE) and described by Persuad and others (1993). These guidelines, along with accepted methods that describe how aquatic organisms are directly affected by contaminated sediment (Persuad and others, 1993) and sediment concentrations developed by Ingersoll and others (1996), were used in data comparisons for this study. These two guidelines (table 5), which are based on bulk sediment, have lower and upper effect levels related to potential impacts on benthic macroinvertebrates for individual trace elements in fresh water. Most trace elements in bed sediments are sorbed to clay and silt-sized particles, and since the samples collected for this study consisted of particle fractions $<63 \mu \mathrm{m}$, the trace element concentrations reported herein may be greater than those for bulk sediment samples. Thus, trace element concentrations in this report may exceed established sediment-quality criteria; such comparisons are provided, however, to place the trace element concentrations in some established context.

Table 5. Bed-sediment quality guidelines for trace elements in bulk sediment [Concentration in milligrams per kilogram dry weight, unless noted otherwise; \%, percent by weight; - , no guidelines. The 'lowest effect level' and 'severe effect level' values are from the Ontario Ministry of Environment (OMOE) (Persuad and others, 1993). The 'effects range low' and 'effects range median' values are sediment effects criteria (SEC) from Ingersoll and others (1996)]

\begin{tabular}{lcccc}
\hline $\begin{array}{l}\text { Trace } \\
\text { element }\end{array}$ & $\begin{array}{c}\text { OMOE } \\
\text { lowest } \\
\text { effect } \\
\text { level }\end{array}$ & $\begin{array}{c}\text { SEC } \\
\text { effects } \\
\text { range } \\
\text { low }\end{array}$ & $\begin{array}{c}\text { OMOE } \\
\text { severe } \\
\text { effect } \\
\text { level }\end{array}$ & $\begin{array}{c}\text { SEC } \\
\text { effects } \\
\text { range } \\
\text { median }\end{array}$ \\
\hline Arsenic & 6 & 13 & 33 & 50 \\
Cadmium & 0.6 & 0.7 & 10 & 3.9 \\
Chromium & 26 & 39 & 110 & 270 \\
Copper & 16 & 41 & 110 & 190 \\
Iron $(\%)$ & 2 & - & 4 & - \\
Lead & 31 & 55 & 250 & 99 \\
Mercury & 0.2 & - & 2 & - \\
Nickel & 16 & 24 & 75 & 45 \\
Zinc & 120 & 110 & 820 & 550 \\
\hline
\end{tabular}


These guidelines and approaches were used to evaluate risks of contamination of sensitive water bodies such as lakes, wetlands, and ponds that accumulate fine-grained sediments and associated trace elements, and to identify contaminant concentration levels that could result in adverse effects to benthic species.

In this report, a comparison of site data with established sediment-quality aquatic-life criteria for benthic organisms is used to provide a more specific indication of those constituents and drainage basins of concern and those that may require further investigation. The association between sampling sites with their probability of adverse effects on aquatic life is intended only for screening purposes. The guideline concentrations used in the assessment may be over or under protective of aquatic organisms, depending on physical, hydrologic, and ecological conditions at a specific site.

Because trace element concentrations in bed-sediment samples from Fort Gordon were determined on the $<63-\mu \mathrm{m}$ size fraction (which contains most of the trace elements), comparison of these concentrations to guideline concentrations in table 5 likely provides a worst-case assessment of sediment-quality conditions.

Aquatic-life criteria for SVOCs were evaluated using procedures developed and used by the U.S. Environmental Protection Agency (USEPA) (U.S. Environmental Protection Agency, 1997a) to analyze data in the National Sediment Inventory. These procedures use the available sediment-quality guidelines for a given constituent to classify sites into probability-of-adverse-effects classes, or tiers, on the basis of measured concentrations at those sites. Tier 1 sites have a high probability of adverse effects on aquatic life; tier 2 sites have an intermediate probability of adverse effects on aquatic life; and tier 3 sites have no indication of adverse effects on aquatic life. The USEPA procedure for classifying sites requires assembling available sediment guidelines for a given constituent, and designating each guideline as either an upper screening value (above which adverse effects may be severe or frequent) or a lower screening value (above which adverse effects may begin or occur occasionally). The first step in determining tier 1 classification for organic compounds is to determine whether the measured concentration exceeds the USEPA proposed sediment-quality criterion (SQC) for protection of benthic organisms with site-specific adjustment for total organic carbon in sediment. For organic constituents with no USEPA SQC, or for any site without information on the total organic carbon content of the bed sediment, the USEPA procedure for tier 1 classification requires that at least two upper screening values be exceeded. The USEPA (1997a,b) uses the following upper screening guidelines for analysis of data in the National Sediment Inventory:

- USEPA SQC (assume 1 percent total organic carbon in sediment for sites with no organic carbon data);

- USEPA sediment-quality advisory level (SQAL) for freshwater aquatic life (assume 1 percent total organic carbon in sediment for sites with no organic carbon data);

- effect range-median (ER-M) developed by Long and Morgan (1991);

- probable effect level (PEL) developed by MacDonald (1994) for the Florida Department of Environmental Protection; and

- apparent effects threshold-high (AET-H) developed by Barrick and others (1988).

For the Fort Gordon bed-sediment data analysis, total organic carbon concentrations were determined at each site; this allowed site-specific organic carbon adjusted assessment of tier 1 classification for three SVOCs for which USEPA SQCs were available (acenaphthene, fluoranthene, phenanthrene). Upper screening values other than USEPA SQCs allowed assessment of tier 1 classification for an additional 16 SVOCs (table 6). Bed sediments at sites at Fort Gordon were designated as exceeding an aquatic-life criterion if the concentration of one or more constituents exceeded the applicable tier 1 boundary conditions listed in table 6 . 
Table 6. Aquatic-life criteria used to establish tier 1 classification for semi-volatile organic compounds in bed sediments

[Tier 1 classification, associated adverse effects to aquatic life are probable; criteria are from U.S. Environmental Protection Agency (1997a,b). CAS, Chemical Abstracts Services; SQC, sediment-quality criterion; SQAL, sediment-quality advisory level; ER-M, effects range-median; AET$\mathrm{H}$, apparent effects threshold; TEL, threshold effects level, $\mathrm{PEL}$, probable effect level; $\mu \mathrm{g} / \mathrm{g}_{\circ}$, microgram per gram organic carbon; $\mu \mathrm{g} / \mathrm{kg}$, microgram per kilogram]

\begin{tabular}{|c|c|c|c|c|c|c|c|}
\hline \multirow[b]{2}{*}{$\begin{array}{l}\text { CAS } \\
\text { number }\end{array}$} & \multirow[b]{2}{*}{ Compound } & \multicolumn{6}{|c|}{ Sediment concentration criterion (dry weight) } \\
\hline & & $\begin{array}{l}\mathrm{SQC}^{\mathrm{l}} \\
\left(\mu \mathrm{g} / \mathrm{g}_{\mathrm{oc}}\right)\end{array}$ & $\begin{array}{l}\mathrm{SQAL}^{2 /} \\
\left(\mu \mathrm{g} / \mathrm{g}_{\mathrm{oc}}\right)\end{array}$ & $\begin{array}{l}\text { ER-M }^{2 /} \\
(\mu \mathrm{g} / \mathrm{kg})\end{array}$ & $\begin{array}{l}\text { AET-H }^{2} \\
(\mu \mathrm{g} / \mathrm{kg})\end{array}$ & $\begin{array}{l}\mathrm{TEL}^{2 /} \\
(\mu \mathrm{g} / \mathrm{kg})\end{array}$ & $\begin{array}{l}\mathrm{PEL}^{2 /} \\
(\mu \mathrm{g} / \mathrm{kg})\end{array}$ \\
\hline
\end{tabular}

$\begin{array}{ll}\text { 83-32-9 } & \text { Acenaphthene } \\ \text { 208-96-8 } & \text { Acenaphthylene } \\ 120-12-7 & \text { Anthracene } \\ 56-55-3 & \text { Benzo[a]anthracene } \\ 50-32-8 & \text { Benzo[a]pyrene } \\ 218-01-9 & \text { Chrysene } \\ 53-70-3 & \text { Dibenzo[a,h]anthracene } \\ 206-44-0 & \text { Fluoranthene } \\ 86-73-7 & \text { Fluorene } \\ 91-20-3 & \text { Naphthalene } \\ 85-01-8 & \text { Phenanthrene } \\ 129-00-0 & \text { Pyrene }\end{array}$

117-81-7 Bis(2-ethylhexyl)phthalate

85-68-7 Butylbenzyl phthalate

84-66-2 Diethyl phthalate

84-74-2 Di-n-butyl phthalate

$\begin{array}{ll}\text { 95-50-1 } & \text { 1,2-Dichlorobenzene } \\ \text { 106-46-7 } & \text { 1,4-Dichlorobenzene } \\ 120-82-1 & 1,2,4-T r i c h l o r o b e n z e n e\end{array}$

\section{Polycyclic aromatic hydrocarbons (PAHs}

130

$\begin{array}{rrcr}640 & 1,300 & 5.9 & 128 \\ 1,100 & 13,000 & 47 & 245 \\ 1,600 & 5,100 & 75 & 693 \\ 1,600 & 3,600 & 89 & 763 \\ 2,800 & 9,200 & 108 & 846 \\ 260 & 970 & 6.2 & 135\end{array}$

620

180

$\begin{array}{rrrrr}54 & 540 & 3,600 & 21.2 & 144 \\ 47 & 2,100 & 2,700 & 35 & 391 \\ & & & & \\ & 2,600 & 16,000 & 153 & 1,398\end{array}$

\section{Phthalates}

$\begin{array}{rrrr} & 1,900 & 182 & 2,650 \\ 1,100 & 900 & \\ 63 & 200 & \\ 1,100 & 1,400 & \end{array}$

\section{Chlorobenzenes}

$\begin{array}{rr}34 & 50 \\ 35 & 120 \\ 920 & 64\end{array}$

${ }^{1 /}$ Classification is tier 1 if concentration of any compound exceeds any SQC (adjusted for the site-specific fraction of organic carbon).

${ }^{2 /}$ Classification is tier 1 if concentration of any compound exceeds at least two of these upper screening values. 


\section{BED-SEDIMENT QUALITY}

The 29 sites at Fort Gordon were evaluated in terms of trace elements and SVOC concentrations in bed sediment. Sites were selected to provide information on the occurrence and distribution of these substances in the study area, and to examine the association between potential source areas of contaminants and magnitude of contaminant concentrations in bed sediments. Replicate and split quality-control samples were collected and analyzed to provide an estimate of the variability in constituent concentration associated with sample collection and analysis.

\section{Trace Elements}

Concentrations for 18 trace elements and total organic carbon (TOC) were determined in the fine-grained fraction $(<63-\mu \mathrm{m})$ of bed-sediment samples collected from 29 sites at Fort Gordon (table 7). Analysis of the sand/silt split in bed-sediment samples shows that the proportion of silt-sized particles $(<63-\mu \mathrm{m})$ ranges from 0.4 percent in a sand-bed stream (site 15) to 37.2 percent downstream from a landfill (site 16). Concentrations of TOC range from 1.1 percent by weight at site 15 to 12.4 percent by weight at a forested, reference site, which contains visibly high amounts of organic material in the bed (site 22). Although a TOC concentration of 2 percent by weight is typical for bed sediments in general (A.J. Horowitz, U.S. Geological Survey, oral commun., 1998), most samples contained TOC concentrations greater than 2 percent by weight. The relatively high TOC concentrations are attributed to analysis of the fine-grained fraction of the sediment sample that contained most of the TOC, and to naturally occurring TOC in the bed sediments that originate from the wetlands and forested areas in the drainage basins.

Trace element concentrations in fine-grained bed sediment samples from most sites exceed concentrations in samples from reference sites at Fort Gordon (table 7). Bed-sediment samples from Soil Erosion Lake (site 2, fig. 1, table 7) contain relatively high concentrations of arsenic (13.6 micrograms per kilogram (mg/kg), barium $(1,100 \mathrm{mg} / \mathrm{kg})$, beryllium $(2.9 \mathrm{mg} / \mathrm{kg})$, chromium $(140 \mathrm{mg} / \mathrm{kg})$, mercury $(1.0 \mathrm{mg} / \mathrm{kg})$, selenium $(3.8 \mathrm{mg} / \mathrm{kg})$, and vanadium $(150 \mathrm{mg} / \mathrm{kg})$. This site receives runoff from a small basin $\left(0.9 \mathrm{mi}^{2}\right)$ where about 45 percent of the land use is military, commercial, and industrial (table 3).

Bed-sediment samples from Butler Creek tributary (site 4, fig. 1) contain relatively high concentrations of antimony $(19.6 \mathrm{mg} / \mathrm{kg})$, cadmium $(6.2 \mathrm{mg} / \mathrm{kg})$, and lead $(310 \mathrm{mg} / \mathrm{kg})$. This site is located in a beaver pond that receives runoff from a $0.2-\mathrm{mi}^{2}$ drainage area comprised of about 57 percent military and industrial uses (table 3 ), including a wash area for motor-pool vehicles.

Bed-sediment samples from Gordon Lake (site 9, fig. 1) contain high concentrations of barium $(720 \mathrm{mg} / \mathrm{kg})$, copper $(67 \mathrm{mg} / \mathrm{kg})$, silver $(12.7 \mathrm{mg} / \mathrm{kg})$, and zinc $(270 \mathrm{mg} / \mathrm{kg})$. The Gordon Lake drainage area is one of the larger drainage basins $(17.5 \mathrm{mi2})$ in the study area. The area contains a mix of land uses including about 14 percent commercial and industrial (table 3 ).

Bed-sediment samples from Sandy Run Creek, near the southern boundary of Fort Gordon (site 23, fig. 1) and Lower Leitner Lake (site 24, fig. 1, table 7), have high cobalt concentrations (19 and $26 \mathrm{mg} / \mathrm{kg}$, respectively) compared to the study area median concentration $(6 \mathrm{mg} / \mathrm{kg}$ ) and the reference site concentrations $(3 \mathrm{mo} 4 \mathrm{mg} / \mathrm{kg})$. These relatively large drainage areas (32.6 and $19.7 \mathrm{mi}^{2}$, respectively) are predominantly forested and barren lands and have no apparent source of cobalt.

Compared to the other sampling sites, sediments from the landfill drainage at McCoy Creek (site 16, fig. 1, table 7) contain the highest concentrations of arsenic $(42 \mathrm{mg} / \mathrm{kg})$, iron $(56 \mathrm{mg} / \mathrm{kg})$ and manganese $(970 \mathrm{mg} / \mathrm{kg})$, and except for zinc, the lowest concentrations of other measured trace elements. The concentration of trace elements at reference sites Middle Fork of Spirit Creek (site 22, fig. 1) and Boggy Gut Creek tributary (site 28, fig. 1) generally are lowest, except for relatively high concentrations of arsenic $(10 \mathrm{mg} / \mathrm{kg})$ and manganese $(190 \mathrm{mg} / \mathrm{kg})$ at site 28 . 
Table 7. Concentration of trace elements and total organic carbon in bed sediment

$[<$, less than; \%, percent by weight; - , no value; $\mathbf{x}$, elements used to compute water-quality scores; (1), to compute median values, the less-than-minimum reporting levels were set equal to one-half the minimum reporting level; reference (2), concentrations from Persaud and others, 1993; background (3), Horowitz, 1987; Note: Concentrations determined on the < 63-micron fraction of bed-sediment samples. Concentrations in milligrams per kilogram, unless otherwise noted]

\begin{tabular}{|c|c|c|c|c|c|c|c|c|c|c|c|c|c|c|c|c|c|c|c|c|}
\hline 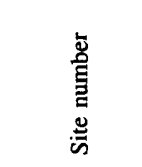 & 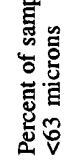 & $\begin{array}{l}\widehat{\Xi} \\
\text { 离 } \\
\text { 音 } \\
\text { 严 }\end{array}$ & 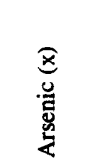 & 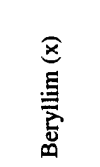 & 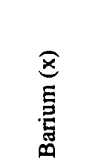 & $\begin{array}{l}\widehat{x} \\
\text { 咅 } \\
\text { Uू }\end{array}$ & $\begin{array}{l}\widehat{x} \\
\underline{\Xi} \\
\text { हू } \\
\text { है }\end{array}$ & $\begin{array}{l}\hat{x} \\
\overline{\tilde{z}} \\
\text { हैं }\end{array}$ & 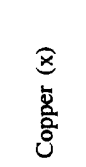 & 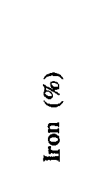 & 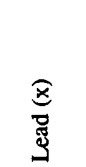 & 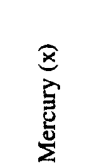 & $\begin{array}{l}\widehat{x} \\
\overline{\bar{v}} \\
\frac{\vec{v}}{z}\end{array}$ & 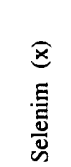 & $\sum_{\bar{n}}^{\frac{5}{2}}$ & 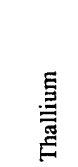 & 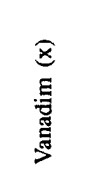 & $\begin{array}{l}\overline{\widehat{x}} \\
\stackrel{\underline{N}}{N}\end{array}$ & 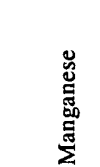 & 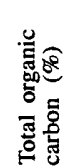 \\
\hline 1 & 13.6 & 1.2 & 10.6 & 2.2 & 590 & 0.4 & 79 & 11 & 22 & 5.1 & 81 & 0.29 & 20 & 2.4 & $<0.5$ & $<50$ & 88 & 120 & 540 & 10.0 \\
\hline 2 & 10.9 & 1.5 & 13.6 & 2.9 & 1100 & 0.4 & 140 & 15 & 41 & 5.0 & 100 & 1.0 & 30 & 3.8 & 0.9 & $<50$ & 150 & 190 & 290 & 3.4 \\
\hline 3 & 5.8 & $\begin{array}{r}1.0 \\
19\end{array}$ & $\begin{array}{l}7.5 \\
0.3\end{array}$ & 2.7 & 540 & 0.1 & 120 & 7 & 21 & 3.5 & 86 & 0.07 & 26 & 0.8 & $<0.5$ & $<50$ & 140 & 93 & 120 & 3.3 \\
\hline $\begin{array}{l}4 \\
5\end{array}$ & $\begin{array}{r}13.4 \\
3.4\end{array}$ & $\begin{array}{l}19.6 \\
0.5\end{array}$ & $\begin{array}{r}9.3 \\
4.5\end{array}$ & $\begin{array}{l}1.4 \\
1.9\end{array}$ & $\begin{array}{l}330 \\
370\end{array}$ & $\begin{array}{l}6.2 \\
0.5\end{array}$ & $\begin{array}{l}110 \\
63\end{array}$ & 6 & 63 & 2.9 & $\begin{array}{r}310 \\
48\end{array}$ & 0.22 & 23 & $\begin{array}{l}1.7 \\
10\end{array}$ & $\begin{array}{r}0.5 \\
-0.5\end{array}$ & $\begin{array}{l}<5 \\
-5\end{array}$ & 130 & 250 & $\begin{array}{r}260 \\
5\end{array}$ & 8.0 \\
\hline $\begin{array}{l}5 \\
6\end{array}$ & $\begin{array}{r}31.4 \\
11.1\end{array}$ & $\begin{array}{l}0.5 \\
0.6\end{array}$ & $\begin{array}{l}4.5 \\
4.1\end{array}$ & $\begin{array}{l}1.9 \\
1.3\end{array}$ & $\begin{array}{l}370 \\
280\end{array}$ & $\begin{array}{r}0.5 \\
<0.1\end{array}$ & $\begin{array}{l}63 \\
75\end{array}$ & $\begin{array}{r}11 \\
3\end{array}$ & 11 & $\begin{array}{l}2.3 \\
1.6\end{array}$ & $\begin{array}{l}48 \\
44\end{array}$ & $\begin{array}{l}0.05 \\
0.0\end{array}$ & $\begin{array}{l}18 \\
16\end{array}$ & & & $\begin{array}{l}<50 \\
<50\end{array}$ & & $\begin{array}{l}63 \\
38\end{array}$ & $\begin{array}{r}570 \\
50\end{array}$ & $\begin{array}{r}6.3 \\
0 ?\end{array}$ \\
\hline 7 & 9.9 & 0.8 & $\begin{array}{l}4.1 \\
4.5\end{array}$ & $\begin{array}{l}1.3 \\
1.1\end{array}$ & $\begin{array}{l}280 \\
270\end{array}$ & $\begin{array}{l}<0.1 \\
<0.1\end{array}$ & $\begin{array}{l}75 \\
78\end{array}$ & $\begin{array}{l}3 \\
4\end{array}$ & $\begin{array}{l}22 \\
31\end{array}$ & $\begin{array}{l}1.6 \\
1.4\end{array}$ & $\begin{array}{l}44 \\
73\end{array}$ & $\begin{array}{l}0.09 \\
0.18\end{array}$ & $\begin{array}{l}16 \\
13\end{array}$ & $\begin{array}{l}1.3 \\
1.2\end{array}$ & $\begin{array}{l}<0.5 \\
<0.5\end{array}$ & $\begin{array}{l}\quad 50 \\
<50\end{array}$ & $\begin{array}{l}82 \\
89\end{array}$ & $\begin{array}{l}38 \\
37\end{array}$ & $\begin{array}{l}50 \\
94\end{array}$ & $\begin{array}{l}9.2 \\
8.2\end{array}$ \\
\hline 8 & 1.6 & 1.2 & 7.1 & $\begin{array}{l}1.5 \\
1.5\end{array}$ & 410 & $\begin{array}{r}<0.1 \\
0.7\end{array}$ & 82 & $\overrightarrow{7}$ & 36 & $\begin{array}{l}1.4 \\
3.6\end{array}$ & $\begin{array}{l}13 \\
81\end{array}$ & 0.18 & 18 & 1.2 & 3.6 & $<5$ & & 120 & 430 & $\begin{array}{l}8.8 \\
8.5\end{array}$ \\
\hline & & 1.6 & 6.4 & 1.9 & 720 & $\begin{array}{l}0.1 \\
1.8\end{array}$ & 100 & 7 & 67 & 3.8 & $\begin{array}{l}91 \\
90\end{array}$ & 0.42 & 22 & 1.4 & $\begin{array}{l}12.0 \\
\end{array}$ & $<5$ & 91 & 270 & 180 & $\begin{array}{l}0.03 \\
7.7\end{array}$ \\
\hline 10 & 30.3 & 1.1 & 13.5 & 1.8 & 580 & $<0.1$ & 100 & 7 & 23 & 5.2 & 76 & 0.15 & 26 & 0.7 & $<0.5$ & $<50$ & 130 & 130 & 180 & 5.1 \\
\hline 11 & 4.9 & 1.2 & 11.8 & 1.7 & 670 & $<0.1$ & 100 & 7 & 25 & 4.4 & 91 & 0.16 & 27 & 0.6 & $<0.5$ & $<50$ & 140 & 110 & 220 & 3.7 \\
\hline 12 & 12.6 & 14.2 & 11.3 & 1.7 & $\begin{array}{r}410 \\
300\end{array}$ & 4.4 & $\begin{array}{l}98 \\
83\end{array}$ & 6 & 61 & 3.4 & 170 & 0.17 & 33 & 1.0 & 0.5 & $<50$ & 150 & 370 & 280 & 9.6 \\
\hline $\begin{array}{l}13 \\
14\end{array}$ & $\begin{array}{l}1.8 \\
4.1\end{array}$ & $\begin{array}{l}2.8 \\
1.5\end{array}$ & $\begin{array}{l}6.0 \\
7.5\end{array}$ & $\begin{array}{l}1.5 \\
1.7\end{array}$ & $\begin{array}{r}590 \\
500\end{array}$ & $\begin{array}{l}0.6 \\
0.1\end{array}$ & $\begin{array}{r}83 \\
110\end{array}$ & $\begin{array}{l}5 \\
6\end{array}$ & $\begin{array}{l}31 \\
33\end{array}$ & $\begin{array}{l}.8 \\
3.8\end{array}$ & $\begin{array}{l}93 \\
74\end{array}$ & $\begin{array}{l}0.41 \\
0.22\end{array}$ & $\begin{array}{l}14 \\
21\end{array}$ & $\begin{array}{l}1.4 \\
2.6\end{array}$ & $\begin{array}{l}4.3 \\
0.5\end{array}$ & $\begin{array}{l}<50 \\
<50\end{array}$ & $\begin{array}{r}83 \\
100\end{array}$ & $\begin{array}{r}88 \\
110\end{array}$ & $\begin{array}{l}170 \\
250\end{array}$ & 7.9 \\
\hline $\begin{array}{l}14 \\
15\end{array}$ & $\begin{array}{l}4.1 \\
0.4\end{array}$ & $\begin{array}{l}1.5 \\
1.1\end{array}$ & $\begin{array}{l}7.5 \\
3.9\end{array}$ & $\begin{array}{l}1.7 \\
1.8\end{array}$ & $\begin{array}{l}500 \\
230\end{array}$ & $<0.1$ & $\begin{array}{l}110 \\
110\end{array}$ & $\begin{array}{l}6 \\
4\end{array}$ & $\begin{array}{l}33 \\
13\end{array}$ & $\begin{array}{l}3.8 \\
1.4\end{array}$ & $\begin{array}{r}74 \\
46\end{array}$ & $\begin{array}{l}0.22 \\
0.10\end{array}$ & $\begin{array}{l}21 \\
19\end{array}$ & $\begin{array}{l}2.6 \\
0.3\end{array}$ & $\begin{array}{r}0.5 \\
<0.5\end{array}$ & $\begin{array}{l}<50 \\
<50\end{array}$ & $\begin{array}{l}100 \\
110\end{array}$ & $\begin{array}{r}110 \\
70\end{array}$ & $\begin{array}{l}250 \\
220\end{array}$ & $\begin{array}{l}7.6 \\
1.1\end{array}$ \\
\hline 16 & $\begin{array}{l}37.4 \\
37.2\end{array}$ & 0.2 & 42 & $<0.5$ & 300 & $<0.1$ & $<5$ & $\begin{array}{l}4 \\
2\end{array}$ & 10 & $\begin{array}{l}1.4 \\
56\end{array}$ & $\begin{array}{r}40 \\
3\end{array}$ & 0.05 & $<5$ & 0.1 & $<0.5$ & $<250$ & 50 & 260 & 970 & 1.7 \\
\hline 17 & 9.5 & 4.6 & 12.7 & 1.4 & 460 & 0.6 & 92 & 6 & 39 & 3.8 & 190 & 0.86 & 24 & 1.2 & 0.8 & $<50$ & 120 & 170 & 210 & 4.1 \\
\hline 18 & 14.8 & 5.2 & 11.2 & 1.7 & 390 & 0.8 & 100 & 6 & 74 & 5.1 & 300 & 0.30 & 20 & 1.3 & 0.6 & $<50$ & 120 & 130 & 110 & 6.4 \\
\hline 19 & 20.1 & 6.7 & 14.0 & 1.6 & 430 & 0.6 & 110 & 6 & 57 & 5.6 & 260 & 0.29 & 21 & 1.3 & 0.7 & $<50$ & 120 & 110 & 100 & 6.4 \\
\hline $\begin{array}{l}20 \\
21\end{array}$ & $\begin{array}{l}13.5 \\
446\end{array}$ & $\begin{array}{l}2.9 \\
0.4\end{array}$ & $\begin{array}{r}12.1 \\
2.8\end{array}$ & $\begin{array}{l}1.7 \\
1.5\end{array}$ & $\begin{array}{l}480 \\
410\end{array}$ & $<<<1.6$ & $\begin{array}{l}95 \\
91\end{array}$ & $\begin{array}{l}5 \\
4\end{array}$ & $\begin{array}{l}40 \\
24\end{array}$ & 4.6 & $\begin{array}{r}110 \\
58\end{array}$ & $\begin{array}{l}0.21 \\
0.15\end{array}$ & $\begin{array}{l}22 \\
15\end{array}$ & $\begin{array}{l}1.2 \\
1.8\end{array}$ & $<0.5$ & $\begin{array}{l}<50 \\
<50\end{array}$ & $\begin{array}{r}120 \\
79\end{array}$ & $\begin{array}{r}150 \\
51\end{array}$ & $\begin{array}{l}200 \\
60\end{array}$ & $\begin{array}{r}5.1 \\
108\end{array}$ \\
\hline $\begin{array}{l}21 \\
22\end{array}$ & $\begin{array}{l}4.6 \\
10.8\end{array}$ & $\begin{array}{l}0.4 \\
0.5\end{array}$ & $\begin{array}{l}2.8 \\
3.5\end{array}$ & $\begin{array}{l}1.5 \\
1.3\end{array}$ & $\begin{array}{l}410 \\
250\end{array}$ & $\begin{array}{l}<0.1 \\
<0.1\end{array}$ & $\begin{array}{l}91 \\
73\end{array}$ & $\begin{array}{l}4 \\
3\end{array}$ & $\begin{array}{l}24 \\
11\end{array}$ & $\begin{array}{l}1.1 \\
1.2\end{array}$ & $\begin{array}{l}58 \\
46\end{array}$ & $\begin{array}{l}0.15 \\
0.07\end{array}$ & $\begin{array}{l}15 \\
16\end{array}$ & $\begin{array}{l}1.8 \\
1.5\end{array}$ & $\begin{array}{r}0.5 \\
<0.5\end{array}$ & $\begin{array}{l}<50 \\
<50\end{array}$ & $\begin{array}{l}79 \\
87\end{array}$ & $\begin{array}{l}51 \\
30\end{array}$ & $\begin{array}{l}60 \\
40\end{array}$ & $\begin{array}{l}10.8 \\
122\end{array}$ \\
\hline 23 & $\begin{array}{r}10.8 \\
3.7\end{array}$ & 0.6 & 6.7 & 1.7 & 350 & $\begin{array}{r}0.1 \\
0.2\end{array}$ & 65 & 19 & 15 & $\begin{array}{l}1.2 \\
4.6\end{array}$ & $\begin{array}{l}40 \\
26\end{array}$ & $\begin{array}{l}.011 \\
0.13\end{array}$ & $\begin{array}{l}10 \\
17\end{array}$ & 1.7 & $<0.5$ & $<50$ & $\begin{array}{l}81 \\
70\end{array}$ & $\begin{array}{l}30 \\
54\end{array}$ & $\begin{array}{l}40 \\
670\end{array}$ & $\begin{array}{l}2.4 \\
7.9\end{array}$ \\
\hline 24 & 26.3 & 0.7 & 7.8 & 2.6 & 450 & 0.7 & 85 & 26 & 21 & 3.8 & 37 & 0.17 & 34 & $\begin{array}{l}1.8 \\
1.8\end{array}$ & $<0.5$ & $<50$ & 93 & 120 & $\begin{array}{l}160 \\
160\end{array}$ & 7.3 \\
\hline 25 & 9.9 & 0.7 & 9.0 & 1.5 & 270 & $<0.1$ & 120 & 8 & 11 & 3.8 & 21 & 0.16 & 20 & 1.4 & $<0.5$ & $<50$ & 150 & 46 & 180 & 3.5 \\
\hline 26 & 12.4 & $\begin{array}{l}1.0 \\
0.5\end{array}$ & 4.7 & 1.0 & $\begin{array}{r}230 \\
350\end{array}$ & 0.2 & 68 & 4 & 13 & 2.2 & 26 & 0.23 & 12 & 0.8 & $<0.5$ & $<50$ & 80 & 31 & 130 & 4.5 \\
\hline $\begin{array}{l}27 \\
28\end{array}$ & 18.6 & $\begin{array}{l}0.5 \\
0.9\end{array}$ & $\begin{array}{r}3.2 \\
104\end{array}$ & $\begin{array}{r}2.0 \\
1.0\end{array}$ & $\begin{array}{l}350 \\
350\end{array}$ & $<0.1$ & $\begin{array}{l}60 \\
68\end{array}$ & $\begin{array}{l}7 \\
4\end{array}$ & $\begin{array}{l}17 \\
17\end{array}$ & 1.7 & $\begin{array}{l}43 \\
35\end{array}$ & 0.2 & $\begin{array}{l}17 \\
17\end{array}$ & 1. & $<0.5$ & $<5$ & 65 & 57 & $\begin{array}{r}80 \\
800\end{array}$ & 9.3 \\
\hline 29 & $\begin{array}{r}4.1 \\
7.9\end{array}$ & $\begin{array}{l}0.9 \\
0.9\end{array}$ & $\begin{array}{l}10.4 \\
5.5\end{array}$ & $\begin{array}{l}.00 \\
2.1\end{array}$ & $\begin{array}{l}350 \\
280\end{array}$ & 0.2 & $\begin{array}{l}68 \\
69\end{array}$ & $\begin{array}{l}4 \\
9\end{array}$ & 20 & $\begin{array}{l}3.5 \\
3.6\end{array}$ & 41 & 0.22 & 22 & $\begin{array}{l}0.8 \\
1.7\end{array}$ & $\begin{array}{l}<0.5 \\
<0.5\end{array}$ & $\begin{array}{l}<50 \\
<50\end{array}$ & 82 & $\begin{array}{l}4 I \\
61\end{array}$ & $\begin{array}{l}100 \\
100\end{array}$ & $\begin{array}{l}1.1 \\
9.9\end{array}$ \\
\hline $\begin{array}{l}\text { minimum } \\
\text { mist }\end{array}$ & 0.4 & 0.2 & 2.8 & $<0.5$ & 230 & $<0.1$ & $<5$ & 2 & 10 & 1.1 & 3 & 0.05 & $<5$ & 0.1 & $<0.5$ & $<50$ & 50 & 30 & 40 & 1.1 \\
\hline maximum & 37.2 & 19.6 & 42 & 2.9 & 1,100 & 6.2 & 140 & 26 & 74 & 56 & 310 & 1.0 & 34 & 3.8 & 12.7 & $<50$ & 150 & 370 & 970 & 12.4 \\
\hline median (1) & 10.4 & 1.1 & 7.5 & 1.7 & 390 & 0.2 & 92 & 6 & 23 & 3.8 & 74 & 0.18 & 20 & 1.3 & $<0.5$ & $<50$ & 93 & 110 & 180 & 7.6 \\
\hline Reference (2) & - & - & 4.2 & - & - & 1.1 & 31 & - & 25 & 3.1 & 23 & 0.1 & 31 & - & - & - & - & 65 & 400 & - \\
\hline Reference (3) & - & $<2$ & $<7$ & - & - & $<1$ & $20-50$ & $<20$ & $20-30$ & $<3.5$ & $20-30$ & $<0.1$ & $20-40$ & $<2$ & $<1$ & - & - & $80-120$ & $<1,400$ & $<2.0$ \\
\hline $\begin{array}{l}\text { Reference } \\
\text { sites } 22 \\
\& 28\end{array}$ & - & $0.5-0.9$ & $\begin{array}{r}3.5- \\
10.4\end{array}$ & $1.0-1.3$ & $\begin{array}{l}250- \\
350\end{array}$ & $<0.1-0.2$ & $68-73$ & $3-4$ & $11-17$ & $1.2-3.5$ & $35-46$ & $\begin{array}{l}0.1- \\
0.22\end{array}$ & $16-17$ & 1.7 & $<0.5$ & $<50$ & $87-92$ & $30-47$ & $40-190$ & $\begin{array}{r}7.7- \\
12.4\end{array}$ \\
\hline
\end{tabular}




\section{Semi-Volatile Organic Compounds}

To facilitate a comparison of SVOCs in bed sediments among sites, the SVOCs were grouped into six classes of compounds; chlorobenzenes, ethers, polycyclic aromatic hydrocarbons (PAHs), phenols, phthalates, and other SVOCs. The compounds included in each class are listed in Appendix A; concentrations of SVOCs samples from each site are listed in plate 1.

Several compounds were corrected for laboratory contamination by subtracting the $95^{\text {th }}$ percentile concentration in laboratory blanks from the measured concentration in each environmental sample (Gilliom and others, 1998). The corrections applied to these compounds were:

$$
\begin{array}{lr}
\text { - Bis(2-ethylhexyl) phthalate: } & 100 \mu \mathrm{g} / \mathrm{kg} \\
\text { - Di-n-butyl phthalate: } & 54 \mu \mathrm{g} / \mathrm{kg} \\
\text { - Butylbenzyl phthalate: } & 64 \mu \mathrm{g} / \mathrm{kg} \\
\text { - Phenol: } & 27 \mu \mathrm{g} / \mathrm{kg} \\
\text { - Diethyl phthalate: } & 25 \mu \mathrm{g} / \mathrm{kg}
\end{array}
$$

The SVOC data are summarized in table 8 for all sites in each class (bottom row of table 8 ) and among classes at each site (each row of table 8). Compounds in the PAH class were detected in bed-sediment samples from 28 of the 29 sites sampled (fig. 1). PAHs were not detected at reference site 22 (fig. 1, table 8).

A high number of PAHs were detected at many sites. Phenols and phthalates also were detected at most sites ( 22 of 29 sites and 26 of 29 sites, respectively). Other SVOCs were detected at fewer sites (18 of 29) compared to the number of detects for PAHs, phenols and phthalates. Chlorobenzenes and ethers were not detected at any of the sites, except for one ether compound detected at site 25 (fig. 1). Although SVOCs were detected at all sites, concentrations at most sites were at the minimum method reporting levels (table 8, plate 1).

The most frequently detected PAHs are pyrene, phenanthrene, and fluoranthene (detected at a minimum of 22 of 29 sites). Pyrene concentrations range from the minimum detection level to $12,200 \mu \mathrm{g} / \mathrm{kg}$, phenanthrene from the minimum detection level to $7,340 \mu \mathrm{g} / \mathrm{kg}$, and fluoranthene from the minimum detection level to $17,100 \mu \mathrm{g} / \mathrm{kg}$. Among the sites, median concentrations for pyrene, phenanthrene, and fluoranthene were 39,15 , and $46 \mu \mathrm{g} / \mathrm{kg}$, respectively (table 8 , plate 1 ).

Other commonly detected compounds include phenols, which were detected at 15 of 29 sites. Phenol concentrations range from the minimum detection level to $195 \mu \mathrm{g} / \mathrm{kg}$ with a median concentration of $3 \mu \mathrm{g} / \mathrm{kg}$. Bis(2-ethylhexyl) phthalate was the most frequently detected phthalate. Concentrations range from the minimum detection level to $4,260 \mu \mathrm{g} / \mathrm{kg}$; the median concentration is $161 \mu \mathrm{g} / \mathrm{kg}$. Other SVOCs compounds were detected at 18 sites. Anthraquinone was the most frequently detected of the SVOC compounds. Concentrations of anthraquinone range from the minimum detection level to $4,230 \mu \mathrm{g} / \mathrm{kg}$ with a median concentration of $25 \mu \mathrm{g} / \mathrm{kg}$ (table 8, plate 1).

Concentrations of SVOCs in bed sediment are highest at sites 12 and 4 (table 8). Bed-sediment samples at site 12 have the highest PAH concentration (fluoranthene, $17,100 \mu \mathrm{g} / \mathrm{kg}$ ) and the highest other SVOC concentration (anthraquinone, $4,230 \mu \mathrm{g} / \mathrm{kg}$ ) (table 8). Site 12 also has the highest sum of PAH concentrations $(82,831 \mu \mathrm{g} / \mathrm{kg}$ ) and sum of other SVOCs $(7,901 \mu \mathrm{g} / \mathrm{kg})$, and the next to highest sum of phthalate concentrations $(4,010 \mu \mathrm{g} / \mathrm{kg})(\mathrm{table} 8)$. Bed-sediment samples at site 4 have the highest phenol concentration (p-Cresol, $759 \mu \mathrm{g} / \mathrm{kg}$ ) and sum of phenol concentrations $(847 \mu \mathrm{g} / \mathrm{kg})$, and the highest phthalate concentration $(4,260 \mu \mathrm{g} / \mathrm{kg})$ and sum of phthalate concentrations $(5,506 \mu \mathrm{g} / \mathrm{kg}$ ) (table 8$)$. The sum of PAH concentrations at site 4 is the second highest of all the sites $(25,045 \mu \mathrm{g} / \mathrm{kg})$. The high SVOC concentrations at sites 12 and 4 are attributed to the size and land use associated with these respective drainage areas. Sites 12 and 4 have relatively small drainage areas of 0.6 and $0.2 \mathrm{mi}^{2}$, respectively. These sites receive runoff from the highest percent commercial and industrial land use areas of all the sites (about 77 and 57 percent, respectively). Comparisons of SVOC data at downstream sampling sites 3 and 11 (fig. 1) indicate that there is some attenuation in concentrations of SVOCs at these downstream sampling locations. 
Bed-sediment samples at site 15 contain the lowest concentrations of SVOCs, even though the drainage area $\left(0.3 \mathrm{mi}^{2}\right)$ is among the smallest of the sites and the percent commercial and industrial land use is about 68 percent. Fluoranthene (about $3 \mu \mathrm{g} / \mathrm{kg}$ ), a PAH, was the only SVOC detected at site 15 .

Bed-sediment samples at the reference sites ( 22 and 28 , fig. 1) contain detectable concentrations of SVOCs; however, the number of detects and sums of concentrations for the factors are among the lowest of all the sites. At site 22, diethyl phthalate and bis(2-ethylhexyl) phthalate were detected at concentrations of 38 and $126 \mu \mathrm{g} / \mathrm{kg}$, respectively. At site 28 , the PAHs—pyrene $(2.5 \mu \mathrm{g} / \mathrm{kg})$, phenanthrene $(0.4 \mu \mathrm{g} / \mathrm{kg})$ and fluoranthene $(10 \mu \mathrm{g} / \mathrm{kg})$-were detected; and the phenols-phenol $(15 \mu \mathrm{g} / \mathrm{kg})$ and p-Cresol $(17 \mu \mathrm{g} / \mathrm{kg})$-were detected (table 8, plate 1$)$.

\section{Quality-Control Data for Bed-Sediment Samples}

Replicate and split quality-control bed-sediment samples were collected at site 24 (fig. 1) to provide an estimate of the error in trace element and SVOC concentrations associated with sample collection, processing, and analysis. Spatial variability within a sampling location is evaluated from relative differences in concentrations between a regular and duplicate sample collected by separate grabs at nearby locations. Bias associated with sample processing and analysis was evaluated from the relative difference in concentrations between splits of the regular and duplicate samples. The overall variability was estimated by determining the standard deviation of regular, duplicate, and split-sample concentrations.

\section{Trace Elements}

Relative differences of trace element concentrations in the regular and duplicate samples and the splits of those samples average about 9 percent, even though the relative difference of particle-size fraction was 66 percent (table 9). Relative differences between concentrations of trace elements in the regular sample and its split, and the duplicate sample and its split, are less than 13 percent, except for antimony (-78 percent in split 1$)$ and cadmium (54 percent in splits 1 and 2).

The standard deviation of concentrations among all quality-control samples is 5 percent or less, except for barium, which are about 10 percent. The low relative differences and overall low standard deviations suggest that trace element concentrations in the fine-grained fraction of bed sediments at sampling sites have a low variation spatially and low bias from sample processing and analysis. Although the sample population is too low for a meaningful in-depth analysis of error, the data collected indicate that sampling error is small relative to the range of sample concentrations at sites.

\section{Semi-Volatile Organic Compounds}

SVOC concentrations in the quality-control samples are somewhat variable, but not atypical of quantitative analysis of SVOCs in bed sediment (table 10). Concentrations of most compounds in the quality-control samples from site 24 were at the minimum method reporting level (Appendix B); therefore, few compounds were available to evaluate variability and bias from sampling, processing, and analysis. Those SVOCs having concentrations reported in at least one of the duplicate quality-control samples are listed in table 10. In duplicate samples having only one reported concentration, that concentration generally was at the minimum method reporting level for the compound in the other sample. Variation in the method reporting levels likely is attributed to the individual sample matrix that effects laboratory extraction efficiency of SVOCs from the sediment (Furlong and others, 1996). In duplicate samples having reported compound concentrations in both samples, the relative differences range from -84 to 149 percent. These limited quality-control data preclude a more meaningful evaluation of variability and bias associated with sampling, processing, and analysis. However, the standard deviation of concentrations for all quality-control samples is relatively low when compared to the range of observed concentrations among the sampling sites. 
Table 8. Summary of bed sediment data for semi-volatile organic compounds

[Concentration in micrograms per kilogram. Concentration of zero indicates value is less than method reporting limit. PAHs, polycyclic aromatic hydrocarbons; SVOCs, semi-volatile organic compounds]

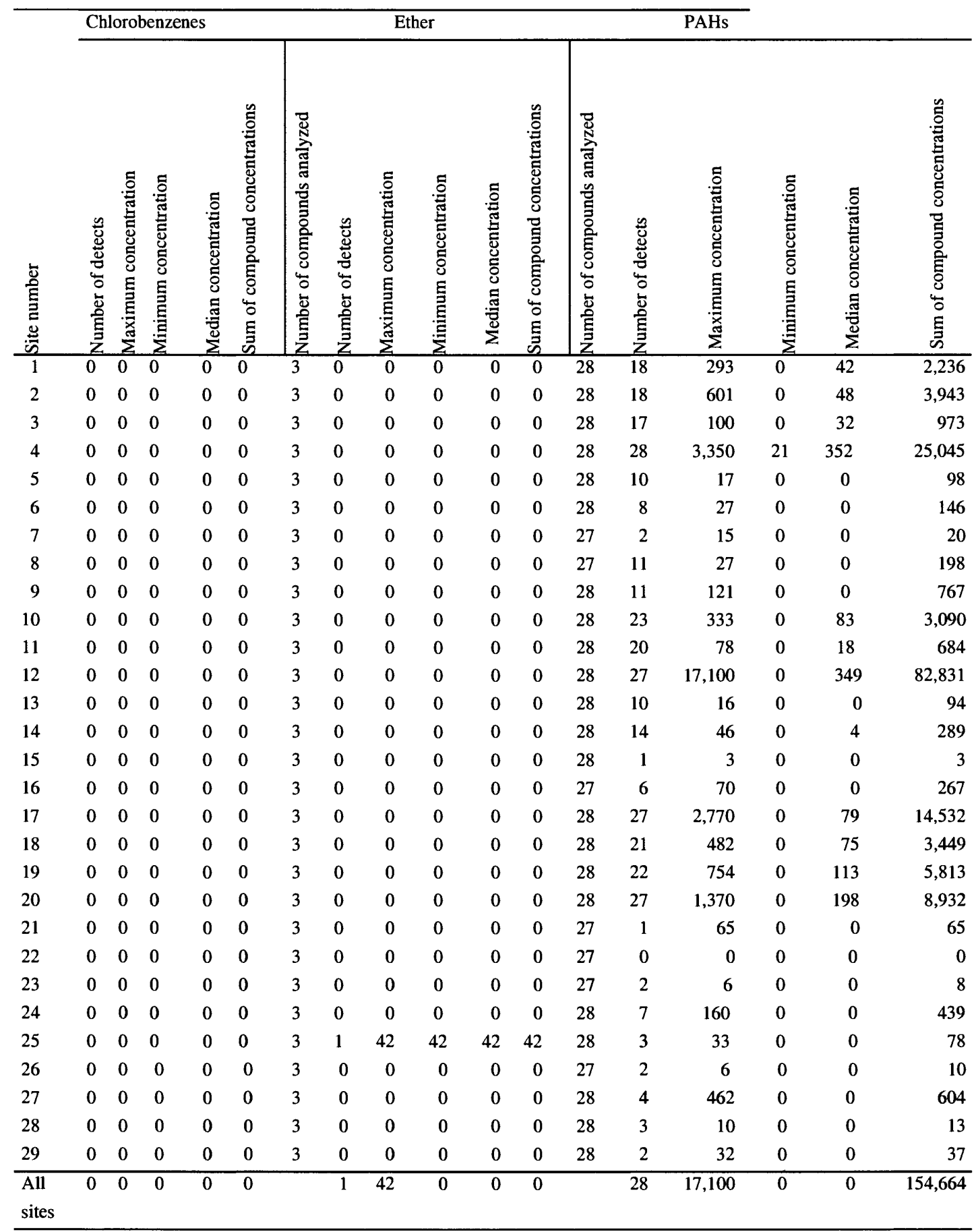


Table 8. Summary of bed sediment data for semi-volatile organic compounds-Continued

[Concentration in micrograms per kilogram. Concentration of zero indicates value is less than method reporting limit. PAHs, polycyclic aromatic hydrocarbons; SVOCs, semi-volatile organic compounds]

\begin{tabular}{|c|c|c|c|c|c|c|c|c|c|c|c|c|c|c|c|c|c|c|}
\hline \multirow[b]{2}{*}{ 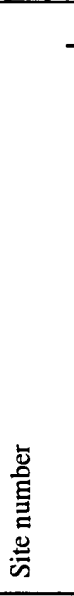 } & \multicolumn{6}{|c|}{ Phenols } & \multicolumn{6}{|c|}{ Phthalates } & \multicolumn{6}{|c|}{ Other SVOCs } \\
\hline & 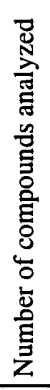 & 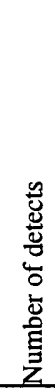 & 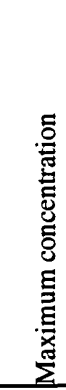 & 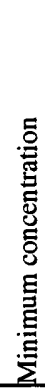 & 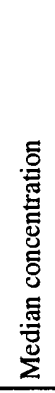 & 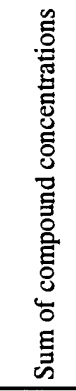 & 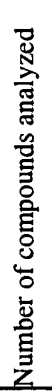 & 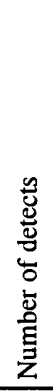 & 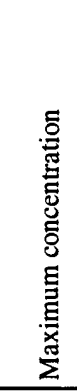 & 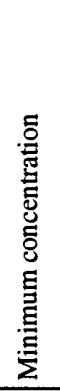 & 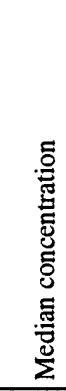 & 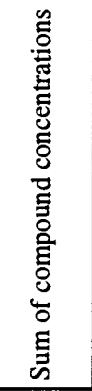 & 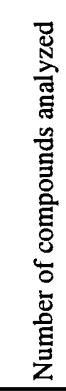 & 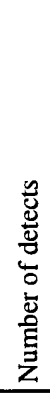 & 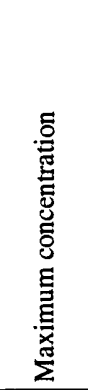 & 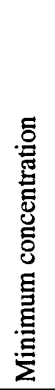 & 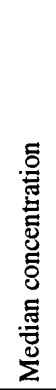 & 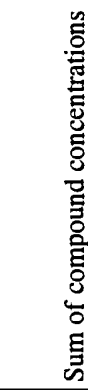 \\
\hline 1 & 6 & 2 & 81 & 0 & 0 & 131 & 6 & 4 & 183 & 0 & 15 & 249 & 17 & 5 & 191 & 0 & 0 & 472 \\
\hline 2 & 6 & 2 & 39 & 0 & 0 & 72 & 6 & 4 & 980 & 0 & 57 & 1,254 & 17 & 5 & 141 & 0 & 0 & 506 \\
\hline 3 & 6 & 2 & 42 & 0 & 0 & 49 & 6 & 3 & 295 & 0 & 6 & 330 & 17 & 3 & 57 & 0 & 0 & 108 \\
\hline 4 & 6 & 2 & 759 & 0 & 0 & 847 & 6 & 4 & 4,260 & 0 & 93 & 5,506 & 17 & 6 & 643 & 0 & 0 & 1,322 \\
\hline 5 & 6 & 1 & 10 & 0 & 0 & 10 & 6 & 1 & 2 & 0 & 0 & 2 & 17 & 0 & 0 & 0 & 0 & 0 \\
\hline 6 & 6 & 1 & 33 & 0 & 0 & 33 & 6 & 1 & 2 & 0 & 0 & 2 & 17 & 0 & 0 & 0 & 0 & 0 \\
\hline 7 & 5 & 1 & 88 & 0 & 0 & 88 & 6 & 1 & 8 & 0 & 0 & 8 & 15 & 2 & 116 & 0 & 0 & 136 \\
\hline 8 & 5 & 1 & 21 & 0 & 0 & 21 & 6 & 1 & 34 & 0 & 0 & 34 & 15 & 1 & 25 & 0 & 0 & 25 \\
\hline 9 & 5 & 0 & 0 & 0 & 0 & 0 & 6 & 3 & 1,880 & 0 & 6 & 1,982 & 15 & 0 & 0 & 0 & 0 & 0 \\
\hline 10 & 6 & 2 & 49 & 0 & 0 & 65 & 6 & 5 & 161 & 0 & 11 & 221 & 17 & 4 & 105 & 0 & 0 & 194 \\
\hline 11 & 6 & 1 & 14 & 0 & 0 & 14 & 6 & 1 & 2 & 0 & 0 & 2 & 17 & 5 & 24 & 0 & 0 & 62 \\
\hline 12 & 6 & 2 & 195 & 0 & 0 & 309 & 6 & 5 & 4,010 & 0 & 133 & 4,807 & 17 & 6 & 4,230 & 0 & 0 & 7,901 \\
\hline 13 & 6 & 1 & 66 & 0 & 0 & 66 & 6 & 2 & 265 & 0 & 0 & 281 & 17 & 0 & 0 & 0 & 0 & 0 \\
\hline 14 & 6 & 1 & 12 & 0 & 0 & 12 & 6 & 0 & 0 & 0 & 0 & 0 & 17 & 1 & 37 & 0 & 0 & 37 \\
\hline 15 & 6 & 0 & 0 & 0 & 0 & 0 & 6 & 0 & 0 & 0 & 0 & 0 & 17 & 0 & 0 & 0 & 0 & 0 \\
\hline 16 & 5 & 0 & 0 & 0 & 0 & 0 & 6 & 3 & 39 & 0 & 2 & 63 & 15 & 0 & 0 & 0 & 0 & 0 \\
\hline 17 & 6 & 2 & 479 & 0 & 0 & 496 & 6 & 3 & 506 & 0 & 3 & 540 & 17 & 6 & 718 & 0 & 0 & 1,341 \\
\hline 18 & 7 & 3 & 128 & 0 & 0 & 244 & 6 & 2 & 265 & 0 & 0 & 304 & 17 & 2 & 183 & 0 & 0 & 241 \\
\hline 19 & 6 & 2 & 204 & 0 & 0 & 235 & 6 & 2 & 1,280 & 0 & 0 & 1,299 & 17 & 3 & 249 & 0 & 0 & 386 \\
\hline 20 & 6 & 3 & 99 & 0 & 0 & 177 & 6 & 4 & 847 & 0 & 1 & 943 & 17 & 5 & 258 & 0 & 0 & 545 \\
\hline 21 & 5 & 0 & 0 & 0 & 0 & 0 & 6 & 4 & 1,840 & 0 & 164 & 2,423 & 15 & 0 & 0 & 0 & 0 & 0 \\
\hline 22 & 5 & 0 & 0 & 0 & 0 & 0 & 6 & 2 & 126 & 0 & 0 & 164 & 15 & 0 & 0 & 0 & 0 & 0 \\
\hline 23 & 5 & 0 & 0 & 0 & 0 & 0 & 6 & 2 & 118 & 0 & 0 & 134 & 15 & 0 & 0 & 0 & 0 & 0 \\
\hline 24 & 6 & 1 & 13 & 0 & 0 & 13 & 6 & 3 & 61 & 0 & 8 & 103 & 17 & 0 & 0 & 0 & 0 & 0 \\
\hline 25 & 7 & 3 & 140 & 0 & 0 & 196 & 6 & 1 & 20 & 0 & 0 & 20 & 17 & 1 & 72 & 0 & 0 & 72 \\
\hline 26 & 5 & 0 & 0 & 0 & 0 & 0 & 6 & 2 & 208 & 0 & 0 & 217 & 15 & 1 & 42 & 0 & 0 & 42 \\
\hline 27 & 6 & 1 & 59 & 0 & 0 & 59 & 6 & 1 & 132 & 0 & 0 & 132 & 17 & 1 & 40 & 0 & 0 & 40 \\
\hline 28 & 6 & 2 & 17 & 0 & 0 & 20 & 6 & 0 & 0 & 0 & 0 & 0 & 17 & 0 & 0 & 0 & 0 & 0 \\
\hline 29 & 6 & 2 & 57 & 0 & 0 & 74 & 6 & 2 & 166 & 0 & 0 & 216 & 17 & 1 & 47 & 0 & 0 & 47 \\
\hline $\begin{array}{r}\text { All } \\
\text { sites }\end{array}$ & & 22 & 759 & 0 & 0 & 3,230 & & 26 & 4,260 & 0 & 0 & 21,235 & & 18 & 4,230 & 0 & 0 & 13,477 \\
\hline
\end{tabular}


Table 9. Concentration of trace elements in quality-control samples

[Concentrations in milligrams per kilogram unless noted otherwise; sdev, standard deviation of mean, \%, percent by weight (grams per 100 grams), --, no value; D, duplicate; S1, split 1; S2, split 2; <, less than]

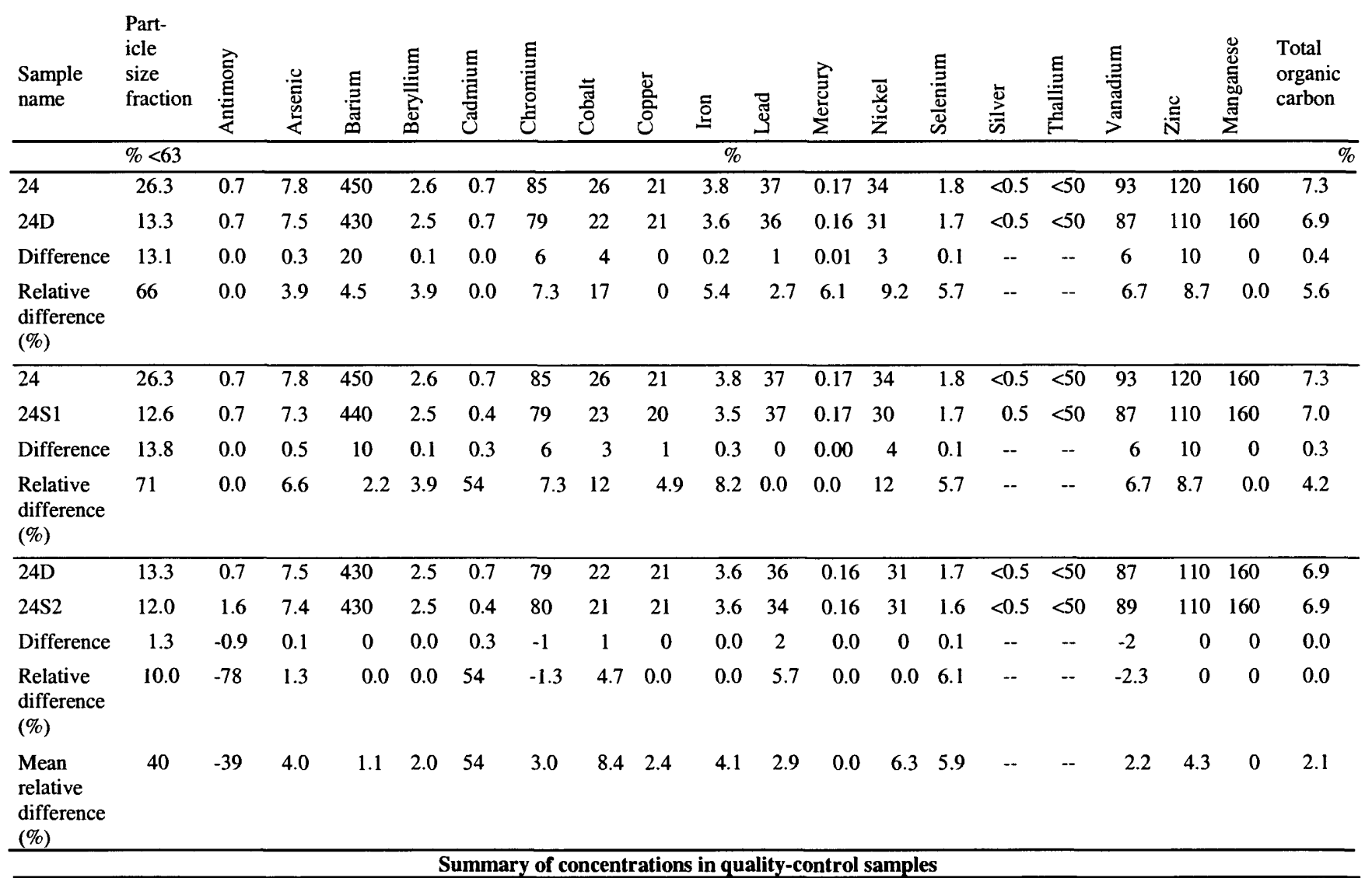

\begin{tabular}{|c|c|c|c|c|c|c|c|c|c|c|c|c|c|c|c|c|c|c|c|c|}
\hline & $\%<63$ & & & & & & & & & $\%$ & & & & & & & & & & $\%$ \\
\hline 24 & 26.3 & 0.7 & 7.8 & 450 & 2.6 & 0.7 & 85 & 26 & 21 & 3.8 & 37 & 0.17 & 34 & 1.8 & $<0.5$ & $<50$ & 93 & 120 & 160 & 7.3 \\
\hline $24 \mathrm{~S} 2$ & 12.0 & 1.6 & 7.4 & 430 & 2.5 & 0.4 & 80 & 21 & 21 & 3.6 & 34 & 0.16 & 31 & 1.6 & $<0.5$ & $<50$ & 89 & 110 & 160 & 6.9 \\
\hline Mean & 16.0 & 0.9 & 7.5 & 438 & 2.5 & 0.6 & 81 & 23 & 21 & 3.6 & 36 & 0.2 & 32 & 1.7 & - & -- & 89 & 113 & 160 & 7.0 \\
\hline sdev & 6.9 & 0.5 & 0.2 & 9.6 & 0.1 & 0.2 & 2.9 & 2.2 & 0.5 & 0.1 & 1.4 & 0.0 & 1.7 & 0.1 & -- & - & 2.8 & 5.0 & 0.0 & 0.2 \\
\hline
\end{tabular}


Table 10. Concentration of semi-volatile organic compounds in quality-control samples

[Compounds listed in table were detected in at least one of the quality-control samples; concentrations are in micrograms per kilogram; sdev, standard deviation of mean, \%, percent by weight (grams per 100 grams), --, no value; D, duplicate; S1, split 1;

$\underline{\mathrm{S} 2 \text {, split } 2 ;<\text {, less than] }}$

\begin{tabular}{|c|c|c|c|c|c|c|c|c|c|c|c|c|c|c|c|c|c|c|c|}
\hline \multirow{2}{*}{$\begin{array}{l}\text { Sample } \\
\text { name }\end{array}$} & \multicolumn{11}{|c|}{ PAHs } & \multicolumn{3}{|c|}{ Phenols } & \multicolumn{3}{|c|}{ Phthalates } & \multicolumn{2}{|c|}{$\begin{array}{l}\text { Other } \\
\text { SVOCs }\end{array}$} \\
\hline & 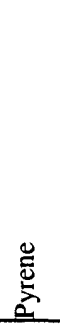 & 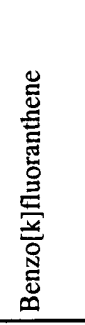 & 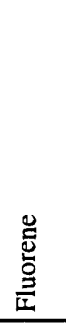 & 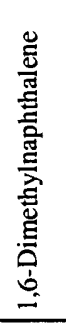 & 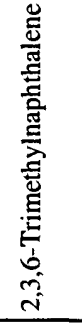 & 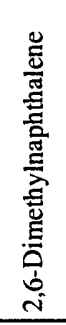 & 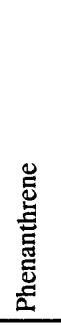 & 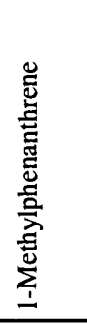 & 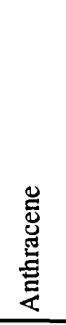 & 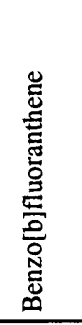 & 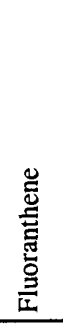 & \begin{tabular}{|l}
$\bar{O}$ \\
$\bar{E}$ \\
$\frac{\mathbf{E}}{2}$ \\
\end{tabular} & 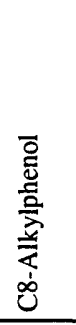 & 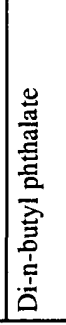 & 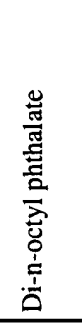 & 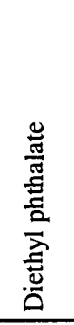 & 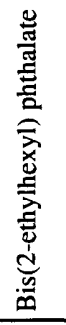 & 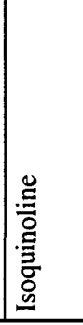 & 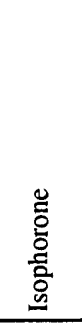 \\
\hline 24 & 46 & $<150$ & 58 & 16 & $<150$ & 160 & 64 & $<150$ & 32 & $<150$ & 62 & 13 & $<150$ & 27 & $<150$ & 61 & 16 & $<150$ & $<150$ \\
\hline 24D & 19 & $<50$ & $<50$ & $<50$ & $<50$ & 136 & 10 & $<50$ & $<50$ & $<50$ & 44 & 28 & $<50$ & 46 & 64 & $<50$ & $<50$ & 14 & $<50$ \\
\hline Difference & 27 & -- & - & -- & -- & 24 & 54 & -- & -- & -- & 18 & -15 & - & -20 & -- & -- & -- & -- & -- \\
\hline $\begin{array}{l}\text { Relative difference } \\
(\%)\end{array}$ & 83 & -- & - & -- & -- & 16 & 146 & -- & -- & -- & 35 & -73 & - & -54 & - & - & -- & -- & -- \\
\hline 24 & 46 & $<150$ & 58 & 16 & $<150$ & 160 & 64 & $<150$ & 32 & $<150$ & 62 & 13 & $<150$ & 27 & $<150$ & 61 & 16 & $<150$ & $<150$ \\
\hline $24 \mathrm{~S} 1$ & 21 & $<50$ & $<50$ & $<50$ & $<50$ & 132 & 10 & $<50$ & $<50$ & $<50$ & 47 & 28 & $<50$ & 65 & $<50$ & $<50$ & $<50$ & $<50$ & $<50$ \\
\hline Difference & 25 & -- & - & -- & -- & 28 & 54 & -- & -- & -- & 15 & -15 & -- & -38 & -- & -- & -- & -- & -- \\
\hline $\begin{array}{l}\text { Relative difference } \\
(\%)\end{array}$ & 75 & -- & -- & -- & - & 19 & 149 & - & -- & -- & 28 & -73 & -- & -84 & -- & -- & - & -- & -- \\
\hline $24 \mathrm{D}$ & 19 & $<50$ & $<50$ & $<50$ & $<50$ & 136 & 10 & $<50$ & $<50$ & $<50$ & 44 & 28 & $<50$ & 46 & 64 & $<50$ & $<50$ & 14 & $<50$ \\
\hline $24 S 2$ & 28 & 47 & $<50$ & $<50$ & $<50$ & 195 & 23 & $<50$ & $<50$ & 34 & 54 & 29 & 290 & 72 & $<50$ & $<50$ & $<50$ & $<50$ & 80 \\
\hline Difference & -9 & -- & -- & -- & -- & -59 & -13 & -- & -- & -- & -10 & -1 & -- & -26 & -- & -- & -- & -- & -- \\
\hline $\begin{array}{l}\text { Relative difference } \\
(\%)\end{array}$ & -39 & -- & -- & -- & -- & -36 & -77 & -- & -- & -- & -21 & -4 & -- & -44 & -- & -- & - & -- & -- \\
\hline \multicolumn{20}{|c|}{ Summary of concentrations of semi-volatile organic compounds in quality-control samples } \\
\hline $\begin{array}{l}\text { Sample } \\
\text { name }\end{array}$ & 志 & 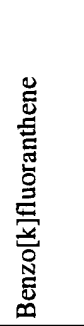 & 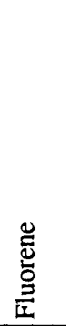 & 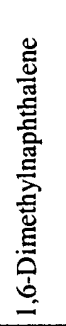 & 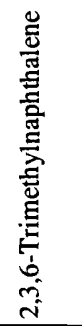 & 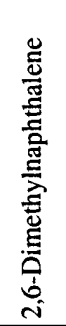 & 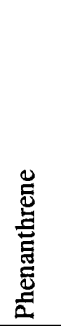 & 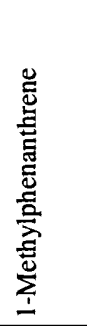 & $\begin{array}{l}\text { 芯 } \\
\text { 苞 } \\
\text { 意 }\end{array}$ & 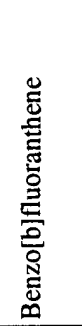 & 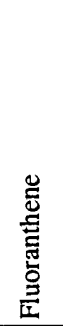 & 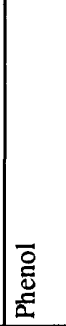 & 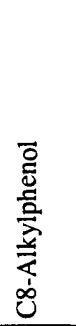 & 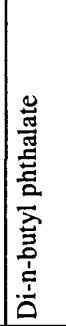 & 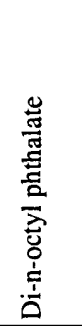 & 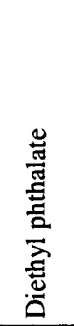 & 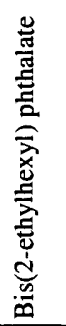 & 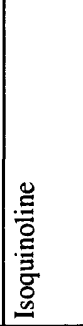 & 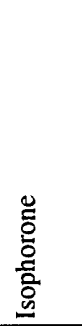 \\
\hline 24 & 46 & $<150$ & 58 & 16 & $<150$ & 160 & 64 & $<150$ & 32 & $<150$ & 62 & 13 & $<150$ & 27 & $<150$ & 61 & 16 & $<150$ & $<150$ \\
\hline 24D & 19 & $<50$ & $<50$ & $<50$ & $<50$ & 136 & 10 & $<50$ & $<50$ & $<50$ & 44 & 28 & $<50$ & 46 & 64 & $<50$ & $<50$ & 14 & $<50$ \\
\hline $24 \mathrm{~S} 1$ & 21 & $<50$ & $<50$ & $<50$ & $<50$ & 132 & 10 & $<50$ & $<50$ & $<50$ & 47 & 28 & $<50$ & 65 & $<50$ & $<50$ & $<50$ & $<50$ & $<50$ \\
\hline $24 S 2$ & 28 & 47 & $<50$ & $<50$ & $<50$ & 195 & 23 & $<50$ & $<50$ & 34 & 54 & 29 & 290 & 72 & $<50$ & $<50$ & $<50$ & $<50$ & 80 \\
\hline Mean & 29 & -- & $\ldots$ & -. & -- & 156 & 27 & - &.- & -. & 52 & 25 & -- & 52 & -- & -- & -. & -- & -. \\
\hline sdev & 12 & -. & -- & - & -- & 29 & 26 & -- & -. & -. & 8 & 8 & -- & 20 & -- & -- & -- & - & - \\
\hline
\end{tabular}




\section{RELATIVE RANKING OF BED-SEDIMENT QUALITY}

Bed-sediment-quality scores based on trace element and SVOC concentrations in bed sediments provide a relative comparison of bed-sediment quality among the sites at Fort Gordon. Data for bed sediment consist of one sample for each site. The methods for ranking each sediment-quality characteristic are described below.

\section{Rankings for Trace Elements}

Sediment-quality scores for sites were determined from equation (1) based on 14 trace elements: antimony, arsenic, barium, beryllium, cadmium, chromium, cobalt, copper, lead, mercury, nickel, selenium, vanadium, and zinc. Because only one sample was collected at each site, the summary value for each element at each site is the value determined by the analysis. The study area median concentration for each element is the median value for all sites sampled. Individual site scores were categorized and ranked from 1 (best) to 4 (worst) on the basis of quartiles of the distribution of study site scores. Ranking categories for the trace elements in bed sediments are summarized in table 11 .

Table 11. Ranking categories for trace elements in bed sediment

\begin{tabular}{llc}
\hline Rank & Percentile & $\begin{array}{c}\text { Bed-sediment } \\
\text { quality scores }\end{array}$ \\
\hline $\begin{array}{l}\text { 1 (lowest concentrations, } \\
\text { best rank) }\end{array}$ & $\leq 25$ & $\leq 0.77$ \\
2 & $>25-50$ & $>0.77-1.06$ \\
3 & $>50-75$ & $>1.06-1.82$ \\
4 (highest concentrations, \\
worst rank)
\end{tabular}

Bed-sediment-quality scores for trace elements at sites range from 0.59 at site 22 (lowest concentration, best rank) to 4.87 at site 4 (highest concentration, worst rank) (table 12). Sites having scores from 0.59 to 0.77 received the lowest (best) rank of 1 (less than or equal to the $25^{\text {th }}$ percentile of all scores) and sites having scores from 1.92 to 4.87 had the highest (worst) rank of 4 (greater than the $75^{\text {th }}$ percentile of all scores).

Sites with a ranking of 1 typically are predominately forested or barren in land uses. Generally, these are areas where land-use activities in the basin minimally affect the trace element quality of bed sediments (table 12). Conversely, sites with a ranking of 4 tend to have the smallest drainage areas and the highest percentages of commercial and industrial land uses. The three highest bed-sediment scores are associated with sites 2,4 , and 12 , which are all ranked as 4 (fig. 1, table 12). These sites also are among the smallest in drainage area, and contain the highest percentages of commercial and industrial land uses (table 12). Two exceptions are McCoys Creek tributary (site 15) and McCoys Creek landfill drainage (site 16). Both sites have ranks of 1, but both drainage areas have relatively high percentages of commercial and industrial land uses (68 and 36 percent, respectively). Bed sediment at site 15 consists of sand deposited at depths of 2 to 3 feet in the stream channel; the sediment contains the smallest percentages of fine-grained material ( 0.4 percent) and TOC (1.1 percent) among all sites (table 7$)$. The low trace element concentrations at this site can be attributed to the poor sorption properties of the bed sediment. Although fine-grained material and associated trace elements from the commercial and industrial areas likely were transported to and along the stream channel during periods of stormwater flow, they apparently were not sorbed to the sandsized bed sediments at this site. 
Table 12. Sediment-quality scores and ranks for trace elements in bed sediment and percent land use or land cover of sampling sites [ranks 1 to 4 , best to worst bed-sediment quality; $\mathrm{mi}^{2}$ square miles; percent, percent of land use or land cover in drainage area]

\begin{tabular}{|c|c|c|c|c|c|c|c|c|c|c|c|}
\hline 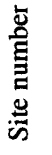 & Site name & $\begin{array}{l}\text { Sediment- } \\
\text { quality score }\end{array}$ & Rank & $\begin{array}{l}\text { Forest } \\
\text { (percent) }\end{array}$ & $\begin{array}{c}\text { Drainage } \\
\text { area } \\
\left(\mathrm{mi}^{2}\right)\end{array}$ & $\begin{array}{l}\text { Barren } \\
\text { (percent) }\end{array}$ & $\begin{array}{c}\text { Commercial, } \\
\text { industrial } \\
\text { (percent) }\end{array}$ & $\begin{array}{c}\text { Resi- } \\
\text { dential } \\
\text { (percent) }\end{array}$ & $\begin{array}{c}\text { Agri- } \\
\text { cultural } \\
\text { (percent) }\end{array}$ & $\begin{array}{l}\text { Wetland } \\
\text { (percent) }\end{array}$ & $\begin{array}{c}\text { Water } \\
\text { (percent) }\end{array}$ \\
\hline 22 & $\begin{array}{l}\text { Middle Fork of Spirit Creek } \\
\text { (headwaters) }\end{array}$ & 0.59 & 1 & 88.8 & 0.5 & 9.5 & 0.1 & 0.0 & 1.2 & 0.3 & 0.0 \\
\hline 6 & South Prong Creek above Ellis Pond & 0.64 & 1 & 76.8 & 5.9 & 20.4 & 0.4 & 0.0 & 2.0 & 0.4 & 0.0 \\
\hline 26 & $\begin{array}{l}\text { Boggy Gut Creek below Claussen } \\
\text { Pond }\end{array}$ & 0.69 & 1 & 64.2 & 21.7 & 21.7 & 0.1 & 0.4 & 9.6 & 3.8 & 0.2 \\
\hline 15 & McCoy Creek tributary at Range Road & 0.70 & 1 & 10.2 & 0.3 & 14.9 & 67.8 & 0.0 & 6.6 & 0.0 & 0.0 \\
\hline 21 & $\begin{array}{l}\text { South Prong Creek near headwaters } \\
\text { Thomas Lake }\end{array}$ & $\begin{array}{l}0.74 \\
0.75\end{array}$ & 1 & $\begin{array}{l}88.4 \\
60.0\end{array}$ & $\begin{array}{l}1.3 \\
3.3\end{array}$ & $\begin{array}{r}9.3 \\
17.4\end{array}$ & $\begin{aligned} & 0.1 \\
& 10.6\end{aligned}$ & $\begin{array}{l}0.0 \\
0.2\end{array}$ & $\begin{aligned} 2.0 \\
11.5\end{aligned}$ & $\begin{array}{l}0.3 \\
0.3\end{array}$ & $\begin{array}{l}0.1 \\
0.0\end{array}$ \\
\hline 16 & 17th Street Landfill drainage & 0.76 & 1 & 7.2 & 0.2 & 48.5 & 36.3 & 0.0 & 7.8 & 0.0 & 0.0 \\
\hline 27 & George Claussen Pond & 0.77 & 1 & 64.0 & 21.3 & 22.0 & 0.0 & 0.4 & 9.5 & 3.8 & 0.2 \\
\hline 28 & $\begin{array}{l}\text { Boggy Gut Creek tributary } \\
\text { (headwaters) }\end{array}$ & 0.77 & 1 & 89.4 & 0.9 & 5.3 & 0.0 & 0.0 & 3.0 & 2.1 & 0.0 \\
\hline 25 & Sandy Run Creek above Ft. Gordon & 0.84 & 2 & 58.6 & 4.7 & 1.9 & 2.0 & 6.3 & 25.6 & 4.6 & 0.8 \\
\hline 5 & Butler Creek at U.S. Highway 78 & 0.91 & 2 & 69.1 & 7.5 & 12.0 & 0.6 & 5.7 & 11.6 & 0.7 & 0.2 \\
\hline 23 & $\begin{array}{l}\text { Sandy Run Creek at U.S. Highway } \\
\text { 1/ State Route } 4\end{array}$ & 0.95 & 2 & 69.2 & 32.6 & 11.5 & 0.6 & 1.3 & 13.2 & 3.2 & 1.0 \\
\hline 3 & Butler Creek Reservoir & 1.04 & 2 & 67.2 & 13.0 & 12.9 & 3.9 & 6.7 & 7.3 & 0.8 & 1.0 \\
\hline 10 & Mirror Lake & 1.06 & 2 & 43.3 & 3.0 & 20.3 & 31.9 & 0.0 & 3.8 & 0.3 & 0.3 \\
\hline 11 & $\begin{array}{l}\text { Spirit Creek tributary above Mirror } \\
\text { Lake }\end{array}$ & 1.08 & 3 & 37.4 & 2.2 & 17.7 & 40.4 & 0.0 & 4.1 & 0.2 & 0.0 \\
\hline 14 & McCoy Creek below Signal Lake & 1.15 & 3 & 35.2 & 3.2 & 20.8 & 32.2 & 0.0 & 11.5 & 0.5 & 0.0 \\
\hline 8 & Spirit Creek at U.S. Highway 1 & 1.22 & 3 & 88.4 & 17.5 & 9.3 & 0.1 & 0.0 & 2.0 & 0.3 & 0.1 \\
\hline 1 & $\begin{array}{l}\text { Butler Creek tributary above } \\
\text { Boardmans Pond }\end{array}$ & 1.33 & 3 & 53.1 & 1.8 & 12.4 & 26.3 & 0.0 & 7.6 & 0.1 & 0.4 \\
\hline 13 & Spirit Creek above Gordon Lake & 1.33 & 3 & 71.3 & 13.0 & 12.5 & 10.9 & 0.0 & 4.9 & 0.3 & 0.1 \\
\hline 24 & Lower Leitner Lake & 1.48 & 3 & 69.0 & 19.7 & 10.1 & 0.8 & 2.0 & 14.0 & 3.0 & 1.1 \\
\hline 20 & North Fork Spirit Creek & 1.82 & 3 & 67.8 & 0.6 & 13.9 & 6.0 & 0.0 & 11.9 & 0.4 & 0.0 \\
\hline 17 & McCoy Creek above Signal Lake & 1.92 & 4 & 46.8 & 1.0 & 16.3 & 32.4 & 0.0 & 4.0 & 0.5 & 0.0 \\
\hline 19 & Marcum Branch above Maxwell Lake & 1.94 & 4 & 66.6 & 2.8 & 17.0 & 8.9 & 0.2 & 6.9 & 0.3 & 0.0 \\
\hline 18 & Marcum Branch below Maxwell Lake & 1.98 & 4 & 66.6 & 2.8 & 17.0 & 8.9 & 0.2 & 6.9 & 0.3 & 0.0 \\
\hline 9 & Gordon Lake & 2.04 & 4 & 66.1 & 17.5 & 14.1 & 13.5 & 0.4 & 5.3 & 0.4 & 0.3 \\
\hline 2 & Soil Erosion Lake & 2.17 & 4 & 28.2 & 0.9 & 16.3 & 44.6 & 0.0 & 10.1 & 0.0 & 0.8 \\
\hline 12 & Spirit Creek tributary near headwaters & 3.85 & 4 & 5.7 & 0.6 & 13.1 & 76.9 & 0.0 & 4.4 & 0.0 & 0.0 \\
\hline 4 & Butler Creek tributary (beaver pond) & 4.87 & 4 & 30.9 & 0.2 & 11.1 & 57.1 & 0.0 & 2.3 & 0.0 & 0.0 \\
\hline
\end{tabular}


The cause of the low concentrations of trace elements at site 16 that resulted in the low ranking is uncertain. A few feet upstream from the site, the stream flows from a culvert that lies beneath a closed landfill. Although the buried culvert is part of the storm drainage system in this basin, a suspected breach in the system beneath the landfill may distribute stormwater flow directly through the culvert (John Wellborn, Fort Gordon Environmental and Natural Resources Management Office, oral commun., 1998). Part or all of the flow may pass through the landfill material, whereby contaminants associated with particulate material likely would be removed from the water by filtration or sorption. Flow through the culvert is sustained by dry weather discharge of ground water that contain high concentrations of dissolved solids and low dissolved oxygen, which is typical of waters affected by leachate from a landfill. Presumably, these conditions within the ground-water environment of the landfill are favorable for the production of relatively high concentrations of soluble iron, manganese, and arsenic and not other trace elements. As ground water flows from the landfill and is exposed to the atmosphere, the soluble forms of these elements apparently are quickly oxidized to insoluble forms that adsorb to the bed sediments. This situation could account for the relatively high concentrations of iron, manganese, and arsenic and low concentrations of other trace elements in the bed sediment directly downstream of the landfill.

Comparison of trace element sediment-quality scores for sites upstream and downstream of lakes and other impoundments indicates that the impoundment of streams effectively traps fine-grained bed sediment and associated contaminants that may otherwise be transported farther downstream. For example, sites 23 and 25 are located downstream and upstream, respectively, of Lower Leitner Lake (site 24), and have lower bed-sediment scores ( 0.95 and 0.84 respectively) (rank 2) than site 24 (score 1.48) (rank 3). Similarly, sites 8 and 13, located downstream and upstream, respectively, of Gordon Lake (site 9), have lower scores (1.22 and 1.33, respectively) (rank 3) than site 9 (score 2.04) (rank 4) (fig. 1, table 12).

\section{Rankings for Semi-Volatile Organic Compounds}

Sediment-quality scores for sites were determined from equation (1) based on four SVOC factors, PAHs, phenols, phthalates, and other SVOCs. Compounds included in the analysis of each factor are listed in Appendix A. Chlorobenzenes and ethers were not included in the computation of scores because few compounds were detected in these factors. The factor summary value for each site is the sum of the detected concentration of compounds for each factor in the sample. The study area median concentration for each factor is the median value of all sites sampled. As was done for trace elements, individual site scores were categorized according to ranks ranging from 1 (best) to 4 (worst) on the basis of quartiles of the distribution of study site scores; categories for the SVOCs in bed sediments are summarized in table 13.

Table 13. Ranking categories for semi-volatile organic compounds in bed sediment

\begin{tabular}{lcc}
\hline Rank & Percentile & $\begin{array}{c}\text { Bed-sediment } \\
\text { quality scores }\end{array}$ \\
\hline $\begin{array}{l}\text { 1 (lowest concentrations, } \\
\text { best rank) }\end{array}$ & $\leq 25$ & $\leq 0.304$ \\
2 & $>25-50$ & $>0.304-1.21$ \\
3 & $>50-75$ & $>1.21-4.40$ \\
$\begin{array}{l}4 \text { (highest concentrations, } \\
\text { worst rank) }\end{array}$ & $>75$ & $>4.40$ \\
\hline
\end{tabular}

Sediment-quality scores for SVOCs at sites range from 0.002 at site 15 (best) to 125 at site 12 (worst) (table 14). Sites having scores ranging from 0.002 to 0.304 received the lowest (best) rank of 1 , and sites having scores ranging from 5.67 to 125 received the highest (worst) rank of 4. Most of the sites having ranks of 1 and 4 for trace elements also have ranks of 1 and 4 for SVOCs, providing additional evidence to support the relation between land use and quality of bed sediments. Sites 4 and 12, which have the highest sediment-quality scores for trace ele-ments also have the highest scores for SVOCs. Low sediment-quality scores for SVOCs at sites 15 and 16 suggest that factors other than drainage area size and land use affect bed-sediment concentrations in a manner similar to that observed for trace elements. The sandy sediments at site 15 and the apparent effects of the landfill on stormwater flow and quality at site 16 are probable causes in the low concentrations and subsequent low scores and ranks for SVOCs. 
Table 14. Sediment-quality scores and ranks for semi-volatile organic compounds in bed sediment and percent land use or land cover of sampling sites

[ranks 1 to 4 , best to worst bed-sediment quality; $\mathrm{mi}^{2}{ }^{2}$ square miles; percent, percent of land use or land cover in drainage area]

\begin{tabular}{|c|c|c|c|c|c|c|c|c|c|c|c|}
\hline 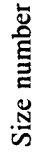 & Site name & $\begin{array}{l}\text { Sediment- } \\
\text { quality score }\end{array}$ & Rank & $\begin{array}{l}\text { Drainage } \\
\text { area } \\
\left(\mathrm{mi}^{2}\right)\end{array}$ & $\begin{array}{c}\text { Forest } \\
\text { (percent) }\end{array}$ & $\begin{array}{l}\text { Barren } \\
\text { (percent) }\end{array}$ & $\begin{array}{l}\text { Residen- } \\
\text { tial } \\
\text { (percent) }\end{array}$ & $\begin{array}{l}\text { Commercial, } \\
\text { industrial } \\
\text { (percent) }\end{array}$ & $\begin{array}{l}\text { Agricult- } \\
\text { ural } \\
\text { (percent) }\end{array}$ & $\begin{array}{l}\text { Wetland } \\
\text { (percent) }\end{array}$ & $\begin{array}{c}\text { Water } \\
\text { (percent) }\end{array}$ \\
\hline 15 & McCoy Creek tributary at Range Road & 0.002 & 1 & 0.3 & 10.2 & 14.9 & 0.0 & 67.8 & 6.6 & 0.0 & 0.0 \\
\hline 28 & Boggy Gut Creek tributary (headwaters) & 0.113 & 1 & 0.9 & 89.4 & 5.3 & 0.0 & 0.0 & 3.0 & 2.1 & 0.0 \\
\hline 5 & Butler Creek at U.S. Highway 78 & 0.140 & 1 & 7.5 & 69.1 & 12.0 & 5.7 & 0.6 & 11.6 & 0.7 & 0.2 \\
\hline 23 & Sandy Run Creek at U.S. 1/ State Route 4 & 0.161 & 1 & 32.6 & 69.2 & 11.5 & 1.3 & 0.6 & 13.2 & 3.2 & 1.0 \\
\hline 22 & Middle Fork of Spirit Creek (headwaters) & 0.190 & 1 & 0.5 & 88.8 & 9.5 & 0.0 & 0.1 & 1.2 & 0.3 & 0.0 \\
\hline 6 & South Prong Creek above Ellis Pond & 0.296 & 1 & 5.9 & 76.8 & 20.4 & 0.0 & 0.4 & 2.0 & 0.4 & 0.0 \\
\hline 16 & $17^{\text {th }}$ Street Landfill drainage & 0.304 & 1 & 0.2 & 7.2 & 48.5 & 0.0 & 36.3 & 7.8 & 0.0 & 0.0 \\
\hline 8 & Spirit Creek at U.S. Highway 1 & 0.464 & 2 & 17.5 & 88.4 & 9.3 & 0.0 & 0.1 & 2.0 & 0.3 & 0.1 \\
\hline 26 & Boggy Gut Creek below Claussen Pond & 0.509 & 2 & 21.7 & 64.2 & 21.7 & 0.4 & 0.1 & 9.6 & 3.8 & 0.2 \\
\hline 14 & McCoy Creek below Signal Lake & 0.528 & 2 & 3.2 & 35.2 & 20.8 & 0.0 & 32.2 & 11.5 & 0.5 & 0.0 \\
\hline 24 & Lower Leitner Lake & 0.566 & 2 & 19.7 & 69.0 & 10.1 & 2.0 & 0.8 & 14.0 & 3.0 & 1.1 \\
\hline 13 & Spirit Creek above Gordon Lake & 0.741 & 2 & 13.0 & 71.3 & 12.5 & 0.0 & 10.9 & 4.9 & 0.3 & 0.1 \\
\hline 29 & Boggy Gut Creek near county lines & 0.936 & 2 & 10.8 & 73.1 & 5.5 & 0.7 & 0.1 & 16.3 & 3.9 & 0.5 \\
\hline 11 & Spirit Creek tributary above Mirror Lake & 1.03 & 2 & 2.2 & 37.4 & 17.7 & 0.0 & 40.4 & 4.1 & 0.2 & 0.0 \\
\hline 27 & George Claussen Pond & 1.21 & 2 & 21.3 & 64.0 & 22.0 & 0.4 & 0.0 & 9.5 & 3.8 & 0.2 \\
\hline 7 & South Prong Creek near headwaters & 1.28 & 3 & 1.3 & 88.4 & 9.3 & 0.0 & 0.1 & 2.0 & 0.3 & 0.1 \\
\hline 25 & Sandy Run Creek above Fort Gordon & 1.51 & 3 & 4.7 & 58.6 & 1.9 & 6.3 & 2.0 & 25.6 & 4.6 & 0.8 \\
\hline 3 & Butler Creek Reservoir & 2.11 & 3 & 13.0 & 67.2 & 12.9 & 6.7 & 3.9 & 7.3 & 0.8 & 1.0 \\
\hline 21 & Thomas Lake & 2.86 & 3 & 3.3 & 60.0 & 17.4 & 0.2 & 10.6 & 11.5 & 0.3 & 0.0 \\
\hline 9 & Gordon Lake & 2.96 & 3 & 17.5 & 66.1 & 14.1 & 0.4 & 13.5 & 5.3 & 0.4 & 0.3 \\
\hline 10 & Mirror Lake & 4.40 & 3 & 3.0 & 43.3 & 20.3 & 0.0 & 31.9 & 3.8 & 0.3 & 0.3 \\
\hline 1 & $\begin{array}{l}\text { Butler Creek tributary above Boardmans } \\
\text { Pond }\end{array}$ & 5.67 & 4 & 1.8 & 53.1 & 12.4 & 0.0 & 26.3 & 7.6 & 0.1 & 0.4 \\
\hline 18 & Marcum Branch below Maxwell Lake & 6.00 & 4 & 2.8 & 66.6 & 17.0 & 0.2 & 8.9 & 6.9 & 0.3 & 0.0 \\
\hline 2 & Soil Erosion Lake & 8.22 & 4 & 0.9 & 28.2 & 16.3 & 0.0 & 44.6 & 10.1 & 0.0 & 0.8 \\
\hline 19 & Marcum Branch above Maxwell Lake & 10.0 & 4 & 2.8 & 66.6 & 17.0 & 0.2 & 8.9 & 6.9 & 0.3 & 0.0 \\
\hline 20 & North Fork Spirit Creek & 12.9 & 4 & 0.6 & 67.8 & 13.9 & 0.0 & 6.0 & 11.9 & 0.4 & 0.0 \\
\hline 17 & McCoy Creek above Signal Lake & 23.6 & 4 & 1.0 & 46.8 & 16.3 & 0.0 & 32.4 & 4.0 & 0.5 & 0.0 \\
\hline 4 & Butler Creek tributary (beaver pond) & 40.2 & 4 & 0.2 & 30.9 & 11.1 & 0.0 & 57.1 & 2.3 & 0.0 & 0.0 \\
\hline 12 & Spirit Creek tributary near headwaters & 125 & 4 & 0.6 & 5.7 & 13.1 & 0.0 & 76.9 & 4.4 & 0.0 & 0.0 \\
\hline
\end{tabular}




\section{COMPARISON OF TRACE ELEMENT AND SEMI-VOLATILE ORGANIC COMPOUND CONCENTRATIONS TO AQUATIC-LIFE CRITERIA FOR BED SEDIMENT}

Trace element concentrations in bed sediment commonly exceed sediment-quality guidelines for bed sediments as developed by Persaud and others (1993) and Ingersoll and others (1996) (table 15). The trace element sediment-quality low-range and high-range guidelines were exceeded at least four times at each site. The highest number of guidelines exceeded (17) occurred at sites $2,4,18$, and 19 (fig. 1, tables 2,15 ). The lowest number of guidelines exceeded (4) occurred at site 22 , a reference site (fig. 1, tables 2,15 ). High-range guidelines, which are the most critical to aquatic-life criteria, were exceeded at 16 sites, and the highest number of high-range guidelines exceeded (4) occurred at site 19 (fig. 1, tables 2, 15).

Chromium and lead exceed OMOE "lowest effects level" and SEC "effects range low" concentrations more than the other trace metals (table 15, low range). Arsenic, cadmium, chromium, iron, and lead exceed either OMOE "severe effect level" or SEC "effects range median" concentrations or both at 16 sites (table 15, high range).

Not all sites exceeding the high-range guidelines have sediment-quality scores that indicate potential sediment-quality problems. Two sites (15 and 16) have sediment-quality ranks of 1 (best), even though bed sediment-quality at site 15 exceeds the OMOE severe effects level for chromium, and bed-site quality at site 16 exceeds the OMOE severe effects level for arsenic and iron. Six of the seven sites $(2,4,12,17,18$, and 19) having ranks of 4 (worst) also have trace metal concentrations that exceeds the high range guidelines; the exception is the Gordon Lake site (9) (fig. 1, tables 2, 15).

The association between trace element concentrations in bed sediment and the potential for adverse effects on aquatic life is intended only for screening purposes. Comparison of concentrations in fine-grained sediments to guideline concentrations based on bed sediments is likely a worst-case assessment of sediment-quality conditions because the fine-grained sediments contain most of the trace elements. Owing to the uncertainty in predicting trace element concentration levels that cause adverse effects to aquatic organisms, a conservative screening approach was used to designate sediment-quality conditions that pose a potential threat to aquatic life. For screening purposes, aquatic-life criteria of bed sediment are exceeded when trace element concentrations exceed at least two high-range guidelines (table 15). This arbitrary screening level is consistent with the screening procedure used by the USEPA for SVOC aquatic-life criteria. Based on this screening method, trace element concentrations in bed sediment exceeded high-range guidelines at seven sites $(2,4,12,16,18,19$, and 20$)$. Five of the seven sites $(2,4,12,18$, and 19) have sediment-quality ranks of 4 (worst); sites 20 and 16 have ranks of 3 and 1, respectively (fig. 1, tables $12,15)$.

SVOCs in bed sediment exceed aquatic-life criteria at sites $4,12,17$, and 20 (fig. 1, table 16). Sites 4 and 12 exceed the aquatic-life criteria for eight SVOCs, site 17 exceeds the criteria for six SVOCs, and site 20 exceeds criteria the for three SVOCs (fig. 1, table 16). Each of these sites have SVOC sediment-quality ranks of 4 (worst) (table 14). A visual comparison of the relative rankings and evaluations of aquatic-life criteria for trace elements and SVOCs in bed sediments at Fort Gordon are depicted in figures 2 and 3, respectively.

Although trace element concentrations in bed sediments at many sites exceed the low concentrations at reference sites, concentration levels exceed aquatic-life criteria guidelines at only seven of the 29 sites. Generally, sites having small drainage areas and large percentages of commercial and industrial uses tend to have the highest concentrations of trace elements in bed sediments (figs. 1,2).

Concentrations of SVOCs for seven sites occurred in the upper quartile range, but only four sites exceeded aquatic-life criteria guidelines (figs. 1, 3). SVOCs were detected most commonly and at the highest concentrations at sites 4 and 12 (fig. 1, table 16). Drainage areas at these sites are small ( 0.2 and $0.6 \mathrm{mi} 2$, respectively) and are dominated by commercial and industrial land uses. Concentrations of SVOCs in the lower quartile range occurred at another seven of the 29 sites $(5,6,15,16,22,23$, and 28$)$ in more typically forested areas (figs. 1, 3; and tables 2,16). 
Table 15. Sites exceeding sediment-quality guidelines for selected trace elements

[x, guideline exceeded; --, guidelines not exceeded: (6), concentration guideline in milligrams per kilogram; the Ontario Ministry of the Environment and Energy are for the Lowest Effect Level (OMOE LEL) and Severe Effect Level (OMOE SEL) (Persaud and others, 1993); sediment effect criteria (SEC) are from Ingersoll and others (1996) for Effects Range Low (SEC ERL) and Effects Range Median (SEC ERM)]

\begin{tabular}{|c|c|c|c|c|c|c|c|c|c|c|c|c|c|c|c|c|c|c|}
\hline \multirow[b]{3}{*}{ 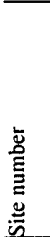 } & \multicolumn{4}{|c|}{ Arsenic } & \multicolumn{4}{|c|}{ Cadmium } & \multicolumn{4}{|c|}{ Chromium } & \multicolumn{4}{|c|}{ Copper } & \multicolumn{2}{|c|}{ Iron } \\
\hline & $\begin{array}{c}\text { OMOE } \\
\text { LEL }\end{array}$ & $\begin{array}{l}\text { SEC } \\
\text { ERL }\end{array}$ & $\begin{array}{l}\text { DMOE } \\
\text { SEL }\end{array}$ & $\begin{array}{c}\text { SEC } \\
\text { ERM }\end{array}$ & $\begin{array}{c}\text { OMOE } \\
\text { LEL }\end{array}$ & $\begin{array}{l}\text { SEC } \\
\text { ERL }\end{array}$ & $\begin{array}{c}\text { OMOE } \\
\text { SEL }\end{array}$ & $\begin{array}{l}\text { SEC } \\
\text { ERM }\end{array}$ & $\begin{array}{c}\text { OMOE } \\
\text { LEL }\end{array}$ & $\begin{array}{l}\text { SEC } \\
\text { ERL }\end{array}$ & $\begin{array}{c}\text { OMOE } \\
\text { SEL }\end{array}$ & $\begin{array}{l}\text { SEC } \\
\text { ERM }\end{array}$ & $\begin{array}{l}\text { OMOE } \\
\text { LEL }\end{array}$ & $\begin{array}{l}\text { SEC } \\
\text { ERL }\end{array}$ & $\begin{array}{c}\text { OMOE } \\
\text { SEL }\end{array}$ & $\begin{array}{l}\text { SEC } \\
\text { ERM }\end{array}$ & $\begin{array}{c}\text { OMOE } \\
\text { LEL }\end{array}$ & $\begin{array}{c}\text { OMOE } \\
\text { SEL }\end{array}$ \\
\hline & $\begin{array}{l}\text { Lo } \\
\text { ran }\end{array}$ & & & & $\begin{array}{l}\text { Lo } \\
\text { ran }\end{array}$ & e & $\begin{array}{l}\mathrm{Hi} \\
\mathrm{ran}\end{array}$ & & Hig & h & $\begin{array}{r}\mathrm{Lc} \\
\mathrm{rar}\end{array}$ & N & $\begin{array}{l}\text { Hig } \\
\text { rang }\end{array}$ & & $\begin{array}{l}\text { Lo } \\
\text { rang }\end{array}$ & we & $\begin{array}{l}\text { High } \\
\text { range }\end{array}$ & $\begin{array}{l}\text { Low } \\
\text { range }\end{array}$ \\
\hline$\frac{5}{1}$ & $\frac{(6)}{x}$ & (13) & (33) & (50) & $(0.6)$ & $(0.7)$ & (10) & (3.9) & (26) & (39) & (110) & $(2 / 0)$ & & (41) & & $(190)$ & & \\
\hline & & & & & & & 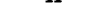 & 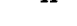 & 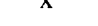 & $\mathrm{X}$ & 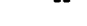 & - & 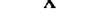 & 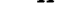 & 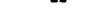 & -- & $\boldsymbol{\lambda}$ & X \\
\hline 2 & $\mathrm{x}$ & $\mathrm{x}$ & -- & -- & -- & - & -- & -- & $\mathrm{x}$ & $\mathrm{x}$ & $\mathrm{x}$ & -- & $\mathrm{x}$ & $\mathrm{x}$ & -- & -- & $\mathrm{x}$ & $\mathrm{x}$ \\
\hline 3 & $\mathrm{x}$ & -- & -- & -- & -- & -- & - & -- & $\mathrm{x}$ & $\mathrm{x}$ & $\mathrm{x}$ & -- & $\mathrm{x}$ & -- & -- & -- & $\mathrm{x}$ & -- \\
\hline 4 & $\mathrm{x}$ & -- & - & -- & $\mathrm{x}$ & $\mathrm{x}$ & -- & -- & $\mathrm{x}$ & $\mathrm{x}$ & $\mathrm{x}$ & -- & $\mathrm{x}$ & $\mathrm{x}$ & - & -- & $\mathrm{x}$ & -- \\
\hline 5 & -- & -- & - & -- & -- & -- & -- & -- & $\mathrm{x}$ & $\mathrm{x}$ & -- & -- & -- & -- & -- & -- & $\mathrm{x}$ & -- \\
\hline 6 & -- & -- & - & -- & -- & -- & -- & -- & $\mathrm{x}$ & $\mathrm{x}$ & -- & -- & $\mathrm{x}$ & -- & -- & -- & -- & -- \\
\hline 7 & -- & -- & - & -- & -- & -- & -- & -- & $\mathrm{x}$ & $\mathrm{x}$ & -- & -- & $\mathrm{x}$ & -- & -- & -- & -- & -- \\
\hline 8 & $\mathrm{x}$ & -- & - & -. & $\mathrm{x}$ & $\mathrm{x}$ & -. & -- & $\mathrm{x}$ & $\mathrm{x}$ & -- & -- & $\mathrm{x}$ & -- & -- & -- & $\mathrm{x}$ & -- \\
\hline 9 & $\mathrm{x}$ & -- & -- & -- & $\mathrm{x}$ & $\mathrm{x}$ & - & -- & $\mathrm{x}$ & $\mathrm{x}$ & -- & -- & $\mathrm{x}$ & $\mathrm{x}$ & -- & -- & $\mathrm{x}$ & -- \\
\hline 10 & $\mathrm{x}$ & $\mathrm{x}$ & -- & -- & -- & -- & -- & -- & $\mathrm{x}$ & $\mathrm{x}$ & -- & -- & $\mathrm{x}$ & -- & -- & -- & $\mathrm{x}$ & $\mathrm{x}$ \\
\hline 11 & $\mathrm{x}$ & -- & -- & -- & -- & -- & -- & -- & $\mathrm{x}$ & $\mathrm{x}$ & -- & -- & $\mathrm{x}$ & -- & -- & -- & $\mathrm{x}$ & $\mathrm{x}$ \\
\hline 12 & $\mathrm{x}$ & -- & -- & -- & $\mathrm{x}$ & $\mathrm{x}$ & -- & $\mathrm{x}$ & $\mathrm{x}$ & $\mathrm{x}$ & -- & -- & $\mathrm{x}$ & $\mathrm{x}$ & -- & -- & $\mathrm{x}$ & -- \\
\hline 13 & $\mathrm{x}$ & - & -- & -- & $\mathrm{x}$ & -- & -- & -- & $\mathrm{x}$ & $x$ & -- & -- & $\mathrm{x}$ & -- & -- & -- & $x$ & -- \\
\hline 14 & $x$ & -- & -- & -. & -. & -- & -- & -- & $x$ & $\mathrm{x}$ & $x$ & -- & $\mathrm{x}$ & -- & -- & -- & $x$ & -- \\
\hline 15 & -- & -- & -- & -- & -- & -- & -- & -- & $\mathrm{x}$ & $\mathrm{x}$ & $\mathrm{x}$ & -. & -- & -- & -- & -- & -- & -- \\
\hline 16 & $x$ & $x$ & $\mathrm{x}$ & .. & -- & -. & -- & -- & -- & -- & -- & -- & $\mathrm{x}$ & -- & -- & -- & $x$ & $x$ \\
\hline 17 & $x$ & -- & -- & -- & $x$ & -- & -- & -- & $x$ & $x$ & -- & -- & $\mathrm{x}$ & $\mathrm{x}$ & -- & -- & $x$ & -. \\
\hline 18 & $\mathrm{x}$ & -. & - & -- & $\mathrm{x}$ & $\mathrm{x}$ & -- & -- & $\mathrm{x}$ & $\mathrm{x}$ & -- & -- & $\mathrm{x}$ & $\mathrm{x}$ & -- & -- & $x$ & $\mathrm{x}$ \\
\hline 19 & $\mathrm{x}$ & $\mathrm{x}$ & -- & -- & $x$ & -- & -- & -- & $x$ & $x$ & $x$ & -- & $x$ & -- & -- & -- & $x$ & $\mathrm{x}$ \\
\hline 20 & $\mathrm{x}$ & -- & -- & -- & $x$ & $x$ & -- & -- & $x$ & $x$ & -- & -- & $\mathrm{x}$ & -- & -- & -- & $\mathrm{x}$ & $x$ \\
\hline 21 & -- & -- & -- & -- & -- & -- & -- & -- & $\mathrm{x}$ & $\mathrm{x}$ & -- & -- & $x$ & -- & -- & -- & -- & -- \\
\hline 22 & -- & -- & -- & -- & -- & -- & -- & -- & $x$ & $\mathrm{x}$ & -- & -- & -- & -- & -- & -. & -- & -- \\
\hline 23 & $\mathrm{x}$ & -- & -- & -- & -- & -- & -- & -- & $x$ & $x$ & -- & -- & -- & -- & -- & -- & $x$ & $\mathrm{x}$ \\
\hline 24 & $\mathrm{x}$ & -- & -- & -- & $\mathrm{x}$ & $\mathrm{x}$ & -- & -- & $x$ & $\mathrm{x}$ & -- & -- & $\mathrm{x}$ & -- & -- & -- & $x$ & -- \\
\hline 25 & $\mathrm{x}$ & $\overrightarrow{-}$ & -- & -- & -- & -- & -- & -- & $x$ & $\mathrm{x}$ & $\mathrm{x}$ & -- & -- & -- & -- & .- & $x$ & -- \\
\hline 26 & -- & -- & -- & -- & -- & -- & -- & -- & $x$ & $\mathrm{x}$ & -- & -- & -- & -- & -- & -- & $x$ & -- \\
\hline 27 & -- & -- & -- & -- & -- & -- & -- & -- & $x$ & $x$ & -- & -- & $x$ & -- & -- & -- & -- & -- \\
\hline 28 & $\mathrm{x}$ & -- & -- & -- & -- & -- & -- & -- & $x$ & $x$ & -- & -- & $x$ & -- & -- & -- & $\mathrm{x}$ & -- \\
\hline 29 & -- & -- & -- & -- & -- & -- & - & -- & $x$ & $x$ & -- & -- & $\mathrm{x}$ & -- & -- & -- & $x$ & -- \\
\hline
\end{tabular}


Table 15. Sites exceeding sediment-quality guidelines for selected trace elements-Continued

[x, guideline exceeded; --, guidelines not exceeded: (6), concentration guideline in milligrams per kilogram; the Ontario Ministry of the Environment and Energy are for the Lowest Effect Level (OMOE LEL) and Severe Effect Level (OMOE SEL) (Persaud and others, 1993; sediment effect criteria (SEC) are from Ingersoll and others (1996) for Effects Range Low (SEC ERL) and Effects Range Median (SEC ERM)]

\begin{tabular}{|c|c|c|c|c|c|c|c|c|c|c|c|c|c|c|c|c|}
\hline \multirow{5}{*}{ 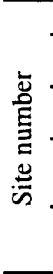 } & \multicolumn{4}{|c|}{ Lead } & \multicolumn{2}{|c|}{ Mercury } & \multicolumn{4}{|c|}{ Nickel } & \multicolumn{4}{|c|}{ Zinc } & \multirow{5}{*}{ 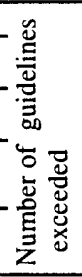 } & \multirow{5}{*}{ 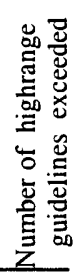 } \\
\hline & OMOE & SEC & OMOE & SEC & OMOE & OMOE & $\mathrm{OMOI}$ & SEC & OMOE & SEC & OMOE & SEC & OMOE & SEC & & \\
\hline & LEL & ERL & SEL & ERM & LEL & SWL & LEL & ERL & SEL & ERM & LEL & ERL & SEL & ERM & & \\
\hline & \multicolumn{2}{|c|}{$\begin{array}{c}\text { Low } \\
\text { range }\end{array}$} & \multicolumn{2}{|c|}{$\begin{array}{c}\text { High } \\
\text { range } \\
\end{array}$} & $\begin{array}{c}\text { Low } \\
\text { range }\end{array}$ & $\begin{array}{l}\text { High } \\
\text { range }\end{array}$ & \multicolumn{2}{|c|}{$\begin{array}{l}\text { Low } \\
\text { range }\end{array}$} & \multicolumn{2}{|c|}{$\begin{array}{c}\text { High } \\
\text { range }\end{array}$} & \multicolumn{2}{|c|}{$\begin{array}{c}\text { Low } \\
\text { range }\end{array}$} & \multicolumn{2}{|c|}{$\begin{array}{l}\text { High } \\
\text { range }\end{array}$} & & \\
\hline & (31) & $(55)$ & $(250)$ & (99) & $(0.2)$ & $(2)$ & (16) & (24) & $(75)$ & (45) & $(120)$ & $(110)$ & $(820)$ & (550) & & \\
\hline 1 & $x$ & $\mathrm{x}$ & - & -- & $\mathrm{x}$ & -- & $x$ & - & -- & -- & $x$ & $x$ & -. & -- & 12 & 1 \\
\hline 2 & $\mathrm{x}$ & $\mathrm{x}$ & -- & $\mathrm{x}$ & $\mathrm{x}$ & -- & $\mathrm{x}$ & $x$ & -- & -- & $\mathrm{x}$ & $\mathrm{x}$ & -- & - & 17 & 3 \\
\hline 3 & $x$ & $\mathrm{x}$ & -- & -- & -- & -- & $\mathrm{x}$ & $x$ & -- & -- & -- & -- & -- & -- & 10 & 1 \\
\hline 4 & $x$ & $\mathrm{x}$ & $\mathrm{x}$ & $\mathrm{x}$ & $\mathrm{x}$ & - & $x$ & -- & -- & -- & $x$ & $\mathrm{x}$ & -- & -- & 17 & 3 \\
\hline 5 & $\mathrm{x}$ & - & -- & -. & - & - & $\mathrm{x}$ & -- & -- & -- & -- & -- & -- & -- & 5 & 0 \\
\hline 6 & $\mathrm{x}$ & - & -- & -- & -- & -- & $\mathrm{x}$ & -- & -- & -- & -- & -- & -- & -- & 5 & 0 \\
\hline 7 & $\mathrm{x}$ & $\mathrm{x}$ & -. & -. & -- & -. & -. & -- & .. & -. & .. & -- & -- & -. & 5 & 0 \\
\hline 8 & $\mathrm{x}$ & $\mathrm{x}$ & -- & -- & -- & -- & $\mathrm{x}$ & -- & -- & -- & $x$ & $x$ & -- & -- & 12 & 0 \\
\hline 9 & $\mathrm{x}$ & $\mathrm{x}$ & -- & -- & $\mathbf{x}$ & -- & $\mathrm{x}$ & -- & -- & -- & $\mathrm{x}$ & $\mathrm{x}$ & -- & -- & 14 & 0 \\
\hline 10 & $x$ & $\mathrm{x}$ & -- & -- & -- & -- & $x$ & $\mathrm{x}$ & -- & -- & $x$ & $x$ & -- & -- & 13 & 1 \\
\hline 11 & $\mathrm{x}$ & $\mathrm{x}$ & - & -- & -- & -- & $\mathrm{x}$ & $\mathrm{x}$ & -- & -- & -- & $x$ & -- & -- & 11 & 1 \\
\hline 12 & $x$ & $\mathbf{x}$ & -- & $\mathrm{x}$ & - & -- & $x$ & $\mathrm{x}$ & -- & -- & $x$ & $x$ & -- & -- & 16 & 2 \\
\hline 13 & $\mathrm{x}$ & $\mathrm{x}$ & -- & -- & $\mathrm{x}$ & -- & - & -- & -- & -- & -- & -- & -- & -- & 9 & 9 \\
\hline 14 & $\mathrm{x}$ & $\mathrm{x}$ & - & -. & $\mathbf{x}$ & -- & $\mathbf{x}$ & -- & -- & - & -- & $x$ & -- & -- & 11 & 1 \\
\hline 15 & $x$ & -- & -- & -. & -- & -- & $x$ & -- & -- & -- & -- & -- & -- & -- & 5 & 1 \\
\hline 16 & -- & -- & -- & -- & -- & -- & -- & -- & -- & -- & $\mathrm{x}$ & $\mathrm{x}$ & -- & -- & 8 & 2 \\
\hline 17 & $x$ & $\mathrm{x}$ & -- & $x$ & $\mathbf{x}$ & -- & $\mathbf{x}$ & $\mathrm{x}$ & -- & -- & $x$ & $\mathrm{x}$ & -- & -- & 14 & 1 \\
\hline 18 & $x$ & $\mathrm{x}$ & $x$ & $\mathrm{x}$ & $x$ & -- & $\mathrm{x}$ & -- & -- & - & $x$ & $x$ & -- & -- & 17 & 3 \\
\hline 19 & $x$ & $\mathrm{x}$ & $x$ & $x$ & $\mathrm{x}$ & -. & $x$ & .- & -- & -. & $x$ & $x$ & -- & .. & 17 & 4 \\
\hline 20 & $\mathrm{x}$ & $\mathrm{x}$ & -- & $x$ & -- & -- & $\mathrm{x}$ & -- & -- & -- & $\mathrm{x}$ & $x$ & -- & -- & 15 & 2 \\
\hline 21 & $\mathrm{x}$ & -- & -- & $x$ & -- & -- & -- & -- & -- & -- & -- & -- & -- & -- & 5 & 0 \\
\hline 22 & $x$ & -- & -- & -- & -- & -- & $x$ & -- & -- & -- & -- & -- & -- & -- & 4 & 0 \\
\hline 23 & $x$ & .- & -. & .. & -. & -- & $x$ & .- & -- & -- & -- & -- & -- & -- & 7 & 1 \\
\hline 24 & $\mathrm{x}$ & -- & -- & -. & -- & - & $x$ & $x$ & -- & -- & $x$ & $x$ & -- & -- & 12 & 0 \\
\hline 25 & $x$ & -- & -- & - & 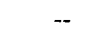 & -- & $x$ & -- & -- & -- & -- & .- & -- & .- & 7 & 1 \\
\hline 26 & $x$ & -- & -- & $x$ & -- & -- & -- & -- & -- & -- & -- & -- & -- & -- & 5 & 0 \\
\hline 27 & $x$ & -- & -- & $x$ & -- & -- & $\mathrm{x}$ & - & -- & -- & -- & -- & -- & -- & 6 & 0 \\
\hline 28 & $x$ & -- & -. & -- & -- & -- & $x$ & -- & -. & -. & -. & - & - & -. & 7 & 0 \\
\hline 29 & $x$ & -- & -- & $\mathbf{x}$ & -- & - & $x$ & -- & -- & -- & -- & -- & -- & -- & 7 & 0 \\
\hline
\end{tabular}




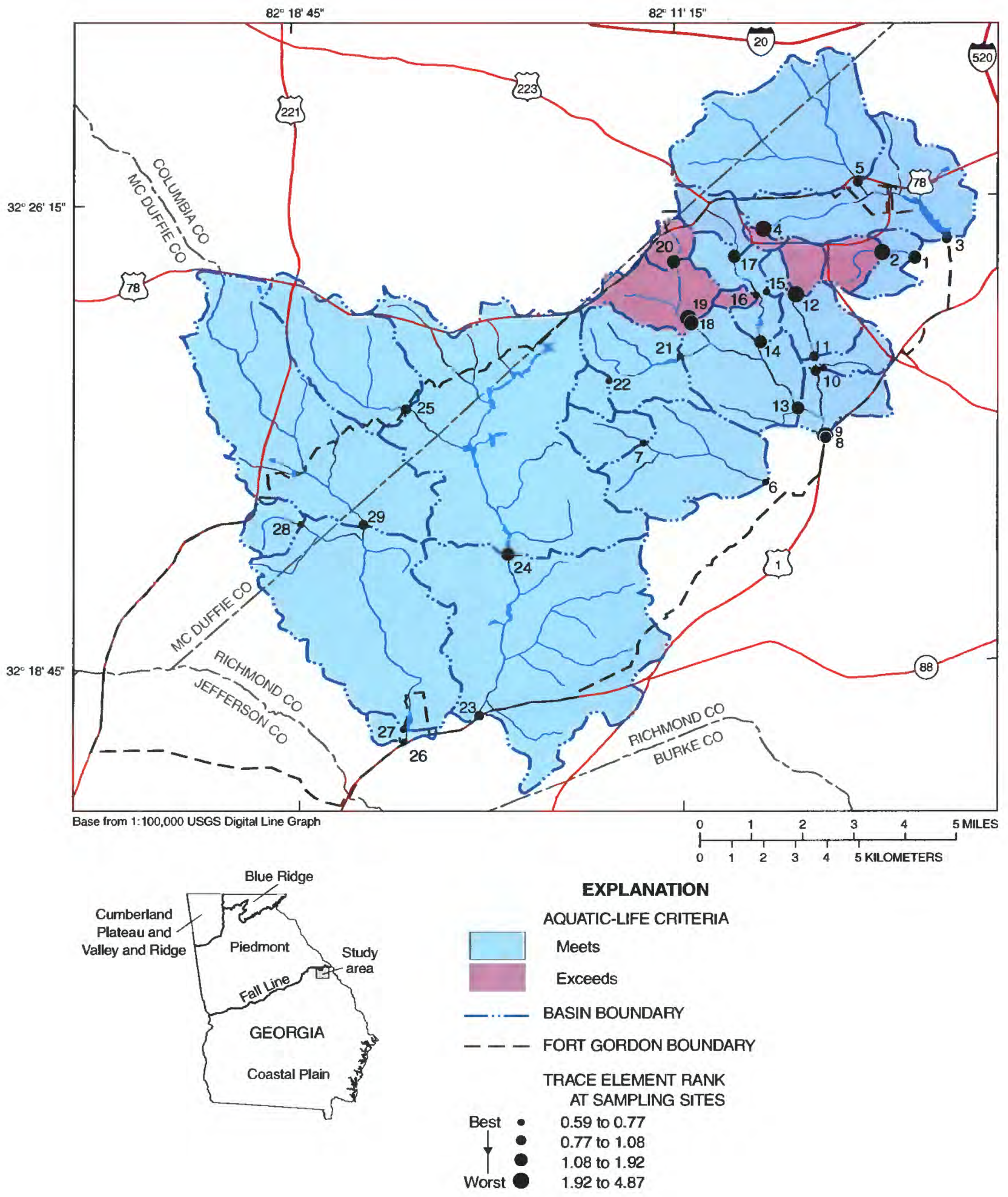

Figure 2. Trace element bed-sediment-quality rankings and aquatic-life criteria comparisons at sampling locations in Fort Gordon, Georgia, study area. 

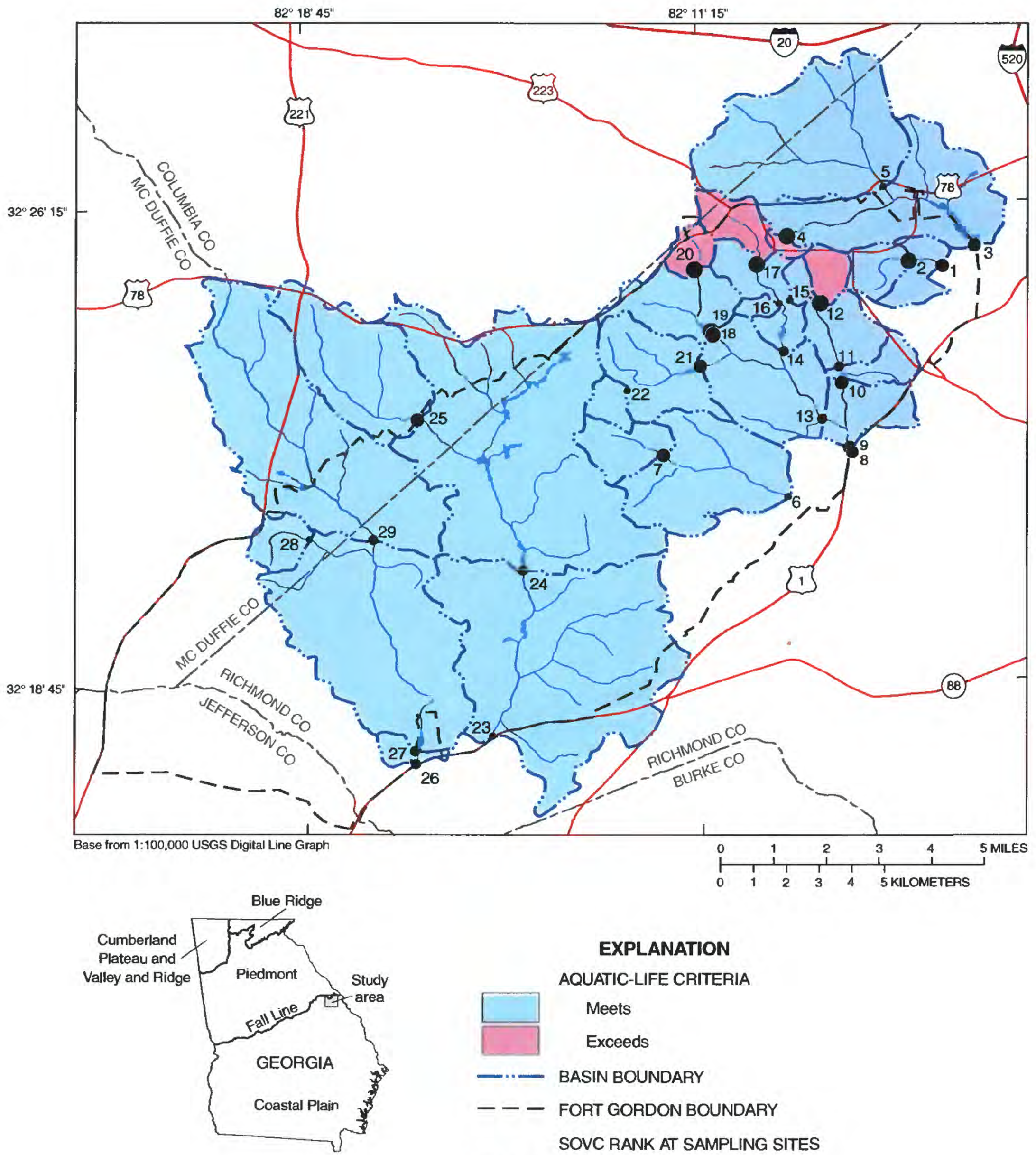

EXPLANATION

AQUATIC-LIFE CRITERIA

Meets

Exceeds

$-\cdots-$ BASIN BOUNDARY
--- FORT GORDON BOUNDARY

SOVC RANK AT SAMPLING SITES

$\begin{array}{cl}\text { Best } & 0.002 \text { to } 0.464 \\ \text { Worst } & 0.464 \text { to } 1.208 \\ 1.208 \text { to } 5.673\end{array}$

Figure 3. Semi-volatile organic compound (SVOC) bed-sediment-quality rankings and aquatic-life criteria comparisons at sampling locations in Fort Gordon, Georgia, study area. 
Table 16. Sites exceeding aquatic-life criteria for semi-volatile organic compounds in bed sediment [SQC, sediment-quality criteria; $x$, indicates compound that exceeded criteria; - , not applicable]

\begin{tabular}{|c|c|c|c|c|c|c|c|c|c|c|}
\hline 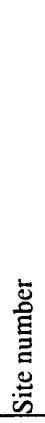 & 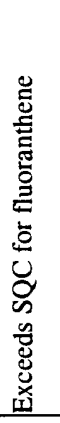 & 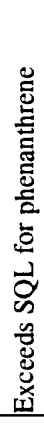 & 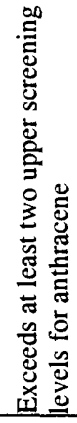 & 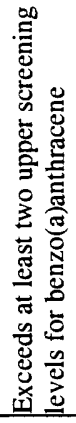 & 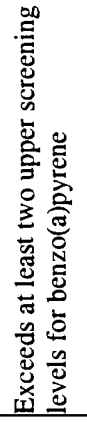 & 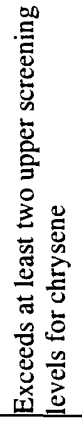 & 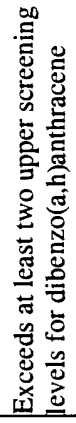 & 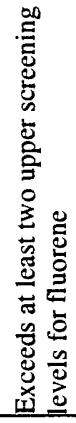 & 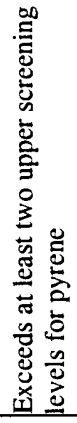 & 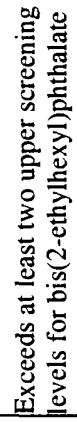 \\
\hline 4 & - & $\mathrm{x}$ & - & $\mathrm{x}$ & $\mathrm{x}$ & $\mathrm{x}$ & $\mathrm{x}$ & $\mathrm{x}$ & $\mathrm{x}$ & $x$ \\
\hline 12 & - & 一 & $\mathrm{x}$ & $\mathrm{x}$ & $\mathbf{x}$ & $\mathrm{x}$ & $\mathrm{x}$ & $\mathrm{x}$ & $\mathrm{x}$ & $x$ \\
\hline 17 & $\mathbf{x}$ & $\mathbf{x}$ & - & 一 & $\mathrm{x}$ & $\mathrm{x}$ & $\mathbf{x}$ & 一 & $\mathrm{x}$ & 一 \\
\hline 20 & 一 & $\mathrm{x}$ & $x$ & - & - & - & - & $\mathrm{x}$ & 一 & - \\
\hline
\end{tabular}

\section{SUMMARY AND CONCLUSIONS}

Analysis of bed-sediment data collected during May 1998 at 29 sites at Fort Gordon, Georgia, were used to describe the occurrence and distribution of trace elements and semi-volatile organic compounds, and to evaluate contaminant contributions from potential pollutant source areas. Potential pollutant source areas include motor pools and maintenance facility operations, personnel training and testing areas, closed landfills, vehicle wash areas, and weapons impact areas.

Concentrations of trace elements and semi-volatile organic compounds in bed sediments were compared to identify drainage basins and receiving streams that may pose a potential risk to aquatic life. These comparisons were made using two different approaches: (1) a relative ranking of trace elements and semi-volatile organic compounds concentrations in bed sediments; and (2) an evaluation of individual trace elements and semi-volatile organic compounds in bed sediments relative to established bed-sediment criteria. Concentrations of 18 trace elements and total organic carbon were determined from analysis of the fine-grained fraction (less than 63 micrometer $(\mu \mathrm{m})$ in size) in bed-sediment samples. Most samples contain total organic carbon concentrations greater than 2 percent by weight, exceeding a level that generally is typical of bed sediments. The relatively high total organic carbon concentrations in bed sediments are attributed to analysis of the fine-grained sediment fraction of the sample and to naturally occurring total organic carbon in the bed sediments that originate from the numerous wetlands and forest cover in the drainage basins at Fort Gordon.

Trace element concentrations in bed-sediment samples at most sites exceed concentrations in bed sediments at reference sites in the study area. Bed sediment collected at three sites having drainage areas of less than 1-square mile $\left(\mathrm{mi}^{2}\right)$ and greater than 45 percent of commercial and industrial land uses, tend to have the most occurrences and highest concentrations of trace elements. However, other factors such as bed-sediment composition and contaminant source areas also affect trace element concentrations. Two sites having drainage areas of less than $1 \mathrm{mi}^{2}$ and greater than 35 percent commercial and industrial land uses have trace element concentrations in bed sediments that are among the lowest of all sites. Apparently, the cleaner and larger grain-size sandy bed sediments in those stream channels provide poor adsorption of metals. Bed sediments at one site (16) contain the highest concentrations of arsenic, iron, and manganese of all sites-likely derived from a landfill located directly upstream of the site. 
Concentrations of 66 semi-volatile organic compounds were determined for bed-sediment samples from 29 sampling sites. The percent of fine-grained material $(<63-\mu \mathrm{m})$ in the bed-sediment samples range from 0.4 to 37 percent, with a median of about 10 percent. Semi-volatile organic compounds were detected in samples from all sites; however, concentrations of most compounds at most sites were at the minimum method reporting level. Concentrations of semi-volatile organic compounds in bed sediments at the reference sites are among the lowest of all the sites. To facilitate comparisons, semi-volatile organic compounds were grouped into six classes-chlorobenzenes, ethers, polycyclic aromatic hydrocarbons (PAHs), phenols, phthalates, and other semi-volatile organic compounds. PAHs, phenols, and phthalates were detected most frequently and at the highest concentrations levels. Chlorobenzenes and ethers were not detected at any sites, except for one ether compound detected at site 25 .

The occurrence and distribution of semi-volatile organic compounds in bed-sediment samples is similar to those for trace elements. Semi-volatile organic compounds were detected more frequently and at higher concentrations at sites having drainage areas of $1 \mathrm{mi} 2$ or less and having 32 percent or more of the land use for commercial and industrial purposes.

A relative ranking procedure based on the concentrations of trace elements and semi-volatile organic compounds provides the means to numerically compare bed-sediment quality among the 29 sampling sites. Sediment-quality scores were calculated from the bed-sediment data, grouped by quartiles, and the quartiles then assigned ranks from 1 (best, $25^{\text {th }}$ percentile or less) to 4 (worst, greater than the $75^{\text {th }}$ percentile).

Most sites having ranks of 1 or 4 for trace elements also have the same ranks for semi-volatile organic compounds. Generally, sampling sites having drainage areas of less than $1 \mathrm{mi} 2$ and greater than 45 percent commercial and industrial land uses, also have the highest sediment-quality scores and the worst ranks. Sites having less than 2 percent commercial and industrial land uses have the lowest sediment-quality scores and ranks regardless of drainage area size. A comparison of sediment-quality scores for sites upstream and downstream of dams and for scores of the sites in impounded stream reaches, indicates that dams effectively trap sediment and associated contaminants that may otherwise be transported farther downstream.

Sediment-quality guidelines for trace elements and aquatic-life criteria for semi-volatile organic compounds were evaluated using approaches based on correlative methodologies and guidelines. These established guidelines and aquatic-life criteria provide a procedure for screening bed-sediment concentration levels to evaluate potential risks of contamination on aquatic life.

Trace element concentrations in the fine-grained bed-sediment samples collected at Fort Gordon commonly exceed sediment-quality guidelines for bed sediments. Arsenic, cadmium, chromium, iron, and lead exceed one or both of the high-range bed-sediment-quality guidelines at 16 sites. Comparison of concentrations in fine-grained sediments to guideline concentrations based on bulk sediment likely results in a worst-case assessment of sedimentquality conditions, because the fine-grained sediments contain most of the trace elements. For this reason, and because of the uncertainty in predicting trace element concentrations, a conservative screening approach was used to designate sediment-quality conditions that may pose a potential threat to aquatic life. For screening purposes, sediment-quality conditions are considered a potential threat to aquatic life when trace element concentrations exceed at least two high-range guidelines. This arbitrary screening level is consistent with the screening procedure used by the U.S. Environmental Protection Agency for aquatic-life criteria. 
Trace element concentrations in bed sediment exceed sediment-quality screening levels at seven sites. Trace elements that exceed the screening levels include arsenic, cadmium, chromium, iron, and lead. Semi-volatile organic compound concentrations in bed sediment exceed aquatic-life criteria established by the U.S. Environmental Protection Agency at four sites. These eight semi-volatile organic compounds include fluoranthene, phenanthrene, anthracene, benze(a)anthracene, chrysene, dibenzo(a,h)anthracene, fluorene and pyrene, and one phthalate; bis(2ethylhexyl)phthalate. Eight polycyclic aromatic hydrocarbon compounds exceed the aquatic-life criteria.

Results of this study suggest a strong relation between trace element and semi-volatile organic compound concentrations in bed sediment and land use in the basins. Relative rankings of these data suggest that the commercial and industrial areas are major sources for trace elements and semi-volatile organic compounds. Sediment-quality screening levels and aquatic-life criteria also are exceeded at these similar type of land-use sites. The potential effects of risks to aquatic life due to elevated trace element and semi-volatile organic compound concentrations at these locations may merit further investigation.

\section{REFERENCES CITED}

Barrick, R.S., Becker, S., Brown, L., Beller, H., and Pastorok, R., 1988, Sediment quality values refinemen, volume Ió Data appendices: 1988 update and evaluation of Puget Sound AET: Seattle, Wash., U.S. Environmental Protection Agency, variously paged.

Furlong, E.T., Vaught, D.G., Merten, L.M., Foreman, W.T., and Gates, P.M., 1996, Methods of analysis by the U.S. Geological Survey National Water Quality Laboratory-Determination of semi-volatile organic compounds in bottom sediment by solvent extraction, gel permeation chromatographic fractionation, and capillary-column gas chromatography/mass spectrometry: U.S. Geological Survey Open-File Report 95-719, 67 p.

Georgia Department of Natural Resources, 1998, Rules of water quality control: Atlanta, Ga., Georgia Department of Natural Resources, Environmental Protection Division, chap. 391-3-6, 19 p.

Gilliom, R.D., Mueller, D.K., and Nowell, L.H., 1998, Methods of comparing water-quality assessment study units, 1992-1995: U.S. Geological Survey Open-File Report 97-589, 54 p.

Horowitz, A.J., 1995, The use of suspended sediment and associated trace elements in water quality studies: International Association of Hydrological Sciences, Special Publication No. 4, 58 p.

Horowitz, A.J., and Elrick, K.A., 1987, The relation of stream sediment surface area, grain size, and composition to trace element chemistry: Applied Geochemistry, v. 2, p. 437-451.

Ingersoll, C.G., Haverland, P.S., Brunson, E.L., Canfield, T.J., Dwyer, F.J., Henke, C.E., Kemble, N.E., Mount, D.R., and Fox, R. G., 1996, Calculation and sediment effect concentrations for the amphipod Hyalella azteca and the midge Chironomus riparius: Great Lakes Reservoir, v. 22, no. 3. p. 602-623.

Long, E.R., and Morgan, L.G., 1991, The potential for biological effects of sediment-sorbed contaminants tested in the National Status and Trends Program: U.S. Department of Commerce, National Oceanic and Atmospheric Administration Technical Memorandum NOS OMA series, no. 52, variously paged.

MacDonald, D.D., 1994, Development and evaluation of sediment quality assessment guidelines; volume 1 of Approach to the assessment of sediment quality in Florida coastal waters: Tallahassee, Fla., MacDonald Environmental Services (Ladysmith, B.C.) report prepared for the Florida Department of Environmental Protection Office of Water Policy, 123 p.

Persaud, D, Jaagumagi, R., and Hayton, A., 1993, Guidelines for the protection and management of aquatic sediment quality in Ontario: Toronto, Ontario Ministry of the Environment and Energy, $24 \mathrm{p}$.

Scudder, B.C., Sullivan, D.J., Fitzpatrick, F.A., and Rheaume, S.J., 1997, Trace elements and synthetic organic compounds in biota and streambed sediment of the western Lake Michigan drainages, 1992-95, National WaterQuality Assessment Program: U.S. Geological Survey Water-Resources Investigations Report 97-4192, 34 p. 


\section{REFERENCES CITED--CONTINUED}

U.S. Environmental Protection Agency, 1997a, The incidence and severity of sediment contamination in surface waters of the United States: U.S. Environmental Protection Agency, Office of Science and Technology, v. 1: National Sediment Quality Survey, U.S. Environmental Protection Agency report to Congress on contaminated sediment, EPA 823-R-97-006, variously paged.

1997b, Multi-Resolution Land Characteristics Interagency Consortium, accessed April 27, 1999, at URL http://www.epa.gov/mricl. 
APPENDICES 
Appendix A. Semi-volatile organic compounds included in chemical analysis of bedsediment samples, Fort Gordon, Georgia, May 1998

[Samples analyzed by the U.S. Geological Survey National Water Quality Laboratory, Denver, Colo.; CAS, Chemical Abstracts Service; surrogate, laboratory quality-control samples used to evaluate analyte recoveries]

\begin{tabular}{|c|c|c|}
\hline Constituent & $\begin{array}{l}\text { CAS } \\
\text { number }\end{array}$ & $\begin{array}{l}\text { WATSTORE } \\
\text { Code }\end{array}$ \\
\hline Terphenyl-d14 (surrogate) & $1718-51-0$ & 49278 \\
\hline 2-Fluorobiphenyl (surrogate) & $321-60-8$ & 49279 \\
\hline Nitrobenzene-d5 (surrogate) & $4165-60-0$ & 49280 \\
\hline \multicolumn{3}{|l|}{ Chlorobenzenes } \\
\hline Hexachlorobenzene & $118-74-1$ & 49343 \\
\hline 1,2,4-Trichlorobenzene & $120-82-1$ & 49438 \\
\hline 1,2-Dichlorobenzene & $95-50-1$ & 49439 \\
\hline 1,3-Dichlorobenzene & $541-73-1$ & 49441 \\
\hline 1,4-Dichlorobenzene & $106-46-7$ & 49442 \\
\hline \multicolumn{3}{|l|}{ Ethers } \\
\hline 4-Bromophenylphenylether & $101-55-3$ & 49454 \\
\hline 4-Chlorophenyl phenyl ether & $7005-72-3$ & 49455 \\
\hline Pentachloroanisole & $1825-21-4$ & 49460 \\
\hline \multicolumn{3}{|c|}{ Polycyclic Aromatic Hydrocarbons (PAHs) } \\
\hline Pyrene & $129-00-0$ & 49387 \\
\hline 1-Methylpyrene & $2381-21-7$ & 49388 \\
\hline Benzo[a]pyrene & $50-32-8$ & 49389 \\
\hline Indeno[1,2,3-cd]pyrene & $193-39-5$ & 49390 \\
\hline Benzo[k]fluoranthene & $207-08-9$ & 49397 \\
\hline 1-Methyl-9H-fluorene & $1730-37-6$ & 49398 \\
\hline Fluorene & $86-73-7$ & 49399 \\
\hline Naphthalene & $91-20-3$ & 49402 \\
\hline 1,2-Dimethylnaphthalene & $573-98-8$ & 49403 \\
\hline 1,6-Dimethylnaphthalene & $575-43-9$ & 49404 \\
\hline 2,3,6-Trimethylnaphthalene & $829-26-5$ & 49405 \\
\hline 2,6-Dimethylnaphthalene & $581-42-0$ & 49406 \\
\hline 2-Chloronaphthalene & $91-58-7$ & 49407 \\
\hline Benzo[ghi]perylene & $191-24-2$ & 49408 \\
\hline Phenanthrene & $85-01-8$ & 49409 \\
\hline 1-Methylphenanthrene & $832-69-9$ & 49410 \\
\hline 4,5-Methylenephenanthrene & 203-64-5 & 49411 \\
\hline Acenaphthylene & $208-96-8$ & 49428 \\
\hline Acenaphthene & $83-32-9$ & 49429 \\
\hline Anthacene & $120-12-7$ & 49434 \\
\hline 2-Methylanthracene & $613-12-7$ & 49435 \\
\hline Benz[a]anthracene & $56-55-3$ & 49436 \\
\hline Chrysene & $218-01-9$ & 49450 \\
\hline Dibenzothiophene & $132-65-0$ & 49452 \\
\hline Benzo[b]fluoranthene & $205-99-2$ & 49458 \\
\hline Dibenzo[a,h]anthracene & $53-70-3$ & 49461 \\
\hline Fluoranthene & $206-44-0$ & 49466 \\
\hline 2-Ethylnaphthalene & $939-27-5$ & 49948 \\
\hline
\end{tabular}


Appendix A. Semi-volatile organic compounds included in chemical analysis of bedsediment samples, Fort Gordon, Georgia, May 1998--Continued

[Samples analyzed by the U.S. Geological Survey National Water Quality Laboratory, Denver, Colo.; CAS,

Chemical Abstracts Service; surrogate, laboratory quality-control samples used to evaluate analyte recoveries]

\begin{tabular}{lll}
\hline Constituent & CAS & WATSTORE \\
& number & Code \\
\hline
\end{tabular}

\section{Phenols}

Phenol

$108-95-2$

4,6-Dinitro-2-methylphenol

$534-52-1 \quad 49419$

3,5-Dimethylphenol

108-68-9 49421

4-Chloro-3-methylphenol

59-50-7

49422

C8-Alkylphenol

N/A

49424

p-Cresol

106-44-5

49451

2-Chlorophenol

95-57-8

49467

Phthalates

Di-n-butyl phthalate

84-74-2 49381

Di-n-octyl phthalate

$117-84-0 \quad 49382$

Diethyl phthalate

84-66-2 49383

Dimethyl phthalate

$131-11-3 \quad 49384$

Bis(2-ethylhexyl) phthalate

$117-81-7 \quad 49426$

Butylbenzyl phthalate

85-68-7 49427

Other semi-volatile organic compounds (SVOCs)

$\begin{array}{lll}2,2 \text { '-Biquinoline } & 119-91-5 & 49391 \\ \text { Quinoline } & 91-22-5 & 49392 \\ \text { Phenanthridine } & 229-87-8 & 49393 \\ \text { Isoquinoline } & 119-65-3 & 49394 \\ \text { 2,4-Dinitrotoluene } & 121-14-2 & 49395 \\ \text { 2,6-Dinitrotoluene } & 606-20-2 & 49396 \\ \text { Isophorone } & 78-59-1 & 49400 \\ \text { Bis(2-Chloroethoxy)methane } & 111-91-1 & 49401 \\ \text { Acridine } & 260-94-6 & 49430 \\ \text { N-Nitrosodi-n-propylamine } & 621-64-7 & 49431 \\ \text { N-Nitrosodiphenylamine } & 86-30-6 & 49433 \\ \text { Anthraquinone } & 84-65-1 & 49437 \\ \text { Azobenzene } & 103-33-3 & 49443 \\ \text { Nitrobenzene } & 98-95-3 & 49444 \\ \text { Pentachloronitrobenzene } & 82-68-8 & 49446 \\ \text { Carbazole } & 86-74-8 & 49449 \\ \text { Benzo[c]cinnoline } & 230-17-1 & 49468\end{array}$


Appendix B. Quality-control data for semi-volatile organic compounds, Fort Gordon, Georgia, May 1998

[Concentrations are in micrograms per kilogram; <, less than; concentrations preceded by a less than symbol are less than the method reporting limit; CAS, Chemical Abstracts Service]

\begin{tabular}{lcclll}
$\begin{array}{l}\text { Watstore } \\
\text { Code }\end{array}$ & CAS number & $\begin{array}{l}\text { Regular } \\
\text { sample }\end{array}$ & $\begin{array}{l}\text { Duplicate } \\
\text { sample }\end{array}$ & $\begin{array}{l}\text { Split of } \\
\text { regular } \\
\text { sample }\end{array}$ & $\begin{array}{l}\text { Split of } \\
\text { duplicate } \\
\text { sample }\end{array}$ \\
\cline { 2 - 6 } & 24 & 24D & $24 S 1$ & $24 S 2$
\end{tabular}

\section{Chlorobenzenes}

Hexachlorobenzene

1,2,4-Trichlorobenzene

I,2-Dichlorobenzene

1,3-Dichlorobenzene

I,4-Dichlorobenzene

\section{Ethers}

4-Bromophenylphenylether

4-Chlorophenyl phenyl ether

Pentachloroanisole

Polycyclic Aromatic Hydrocarbons

Pyrene

1-Methylpyrene

Benzo[a]pyrene

Indeno[1,2,3-cd]pyrene

Benzo[k]fluoranthene

1-Methyl-9H-fluorene

Fluorene

Naphthalene

I,2-Dimethylnaphthalene

1,6-Dimethylnaphthalene

2,3,6-Trimethylnaphthalene

2,6-Dimethylnaphthalene

2-Chloronaphthalene

Benzo[ghi]perylene

Phenanthrene

I-Methylphenanthrene

4,5-Methylenephenanthrene

Acenaphthylene

Acenaphthene

Anthacene

2-Methylanthracene

Benz[a]anthracene

Chrysene

Dibenzothiophene

Benzo[b]fluoranthene

Dibenzo[a,h]anthracene

Fluoranthene

2-Ethylnaphthalene

$\begin{array}{llllll}49343 & 118-74-1 & <150 & <50 & <50 & <50 \\ 49438 & 120-82-1 & <150 & <50 & <50 & <50 \\ 49439 & 95-50-1 & <150 & <50 & <50 & <50 \\ 49441 & 541-73-1 & <150 & <50 & <50 & <50 \\ 49442 & 106-46-7 & <150 & <50 & <50 & <50\end{array}$

$\begin{array}{llllll}49454 & 101-55-3 & <150 & <50 & <50 & <50 \\ 49455 & 7005-72-3 & <150 & <50 & <50 & <50 \\ 49460 & 1825-21-4 & <150 & <50 & <50 & <50\end{array}$

$\begin{array}{rlrrrr}49387 & 129-00-0 & 46 & 19 & 2 \text { I } & 28 \\ 49388 & 2381-21-7 & <150 & <50 & <50 & <50 \\ 49389 & 50-32-8 & <150 & <50 & <50 & <50 \\ 49390 & 193-39-5 & <150 & <50 & <50 & <50 \\ 49397 & 207-08-9 & <150 & <50 & <50 & 47 \\ 49398 & 1730-37-6 & <150 & <50 & <50 & <50 \\ 49399 & 86-73-7 & 58 & <50 & <50 & <50 \\ 49402 & 91-20-3 & <150 & <50 & <50 & <50 \\ 49403 & 573-98-8 & <150 & <50 & <50 & <50 \\ 49404 & 575-43-9 & 16 & <50 & <50 & <50 \\ 49405 & 829-26-5 & <150 & <50 & <50 & <50 \\ 49406 & 581-42-0 & 160 & 136 & 132 & 195 \\ 49407 & 91-58-7 & <150 & <50 & <50 & <50 \\ 49408 & 191-24-2 & <150 & <50 & <50 & <50 \\ 49409 & 85-01-8 & 64 & 10 & 10 & 23 \\ 49410 & 832-69-9 & <150 & <50 & <50 & <50 \\ 49411 & 203-64-5 & <150 & <50 & <50 & <50 \\ 49428 & 208-96-8 & <150 & <50 & <50 & <50 \\ 49429 & 83-32-9 & <150 & <50 & <50 & <50 \\ 49434 & 120-12-7 & 32 & <50 & <50 & <50 \\ 49435 & 613-12-7 & <150 & <50 & <50 & <50 \\ 49436 & 56-55-3 & <150 & <50 & <50 & <50 \\ 49450 & 218-01-9 & <150 & <50 & <50 & <50 \\ 49452 & 132-65-0 & <150 & <50 & <50 & <50 \\ 49458 & 205-99-2 & <150 & <50 & <50 & 34 \\ 49461 & 53-70-3 & <150 & <50 & <50 & <50 \\ 49466 & 206-44-0 & 62 & 44 & 47 & 54 \\ 49948 & 939-27-5 & <150 & <50 & <50 & <50\end{array}$


Appendiix B. Quality-control data for semi-volatile organic compounds, Fort Gordon, Georgia, May 1998-Continued

[Concentrations are in micrograms per kilogram; <, less than; concentrations preceded by a less than symbol are less than the method reporting limit; CAS, Chemical Abstracts Service]

\begin{tabular}{lllllll}
\hline & Watstore & & Regular \\
Compound & CAS number & $\begin{array}{l}\text { Duplicate } \\
\text { sample }\end{array}$ & $\begin{array}{l}\text { Split of } \\
\text { regular } \\
\text { sample }\end{array}$ & $\begin{array}{l}\text { Split of } \\
\text { duplicate } \\
\text { sample }\end{array}$ \\
\cline { 3 - 7 } & & & 24 & $24 \mathrm{D}$ & $24 \mathrm{~S} 1$ & $24 \mathrm{~S} 2$ \\
\hline
\end{tabular}

\section{Phenols}

Phenol

4,6-Dinitro-2-methylphenol

3,5-Dimethylphenol

4-Chloro-3-methylphenol

C8-Alkylphenol

p-Cresol

2-Chlorophenol

$\begin{array}{rccccr}49413 & 108-95-2 & 13 & 28 & 28 & 29 \\ 49419 & 534-52-1 & <50 & <50 & <50 & <50 \\ 49421 & 108-68-9 & <150 & <50 & <50 & <50 \\ 49422 & 59-50-7 & <150 & <50 & <50 & <50 \\ 49424 & \text { N } / \text { A } & <150 & <50 & <50 & 290 \\ 49451 & 106-44-5 & <150 & <50 & <50 & <50 \\ 49467 & 95-57-8 & <150 & <50 & <50 & <50\end{array}$

\section{Phthalates}

Di-n-butyl phthalate

Di-n-octyl phthalate

49381

49382

Diethyl phthalate

Dimethyl phthalate

49383

49384

Bis(2-ethylhexyl) phthalate

49426

Butylbenzyl phthalate

49427

$\begin{array}{lrrrr}84-74-2 & 27 & 46 & 65 & 72 \\ 117-84-0 & <150 & 64 & <50 & <50 \\ 84-66-2 & 61 & <25 & 25 & <25 \\ 131-11-3 & <150 & <50 & <50 & <50 \\ 117-81-7 & 16 & <50 & <50 & <50 \\ 85-68-7 & <150 & <50 & <50 & <50\end{array}$

\section{Semi-Volatile Organic Compounds}

2,2'-Biquinoline
Quinoline
Phenanthridine
Isoquinoline
2,4-Dinitrotoluene
2,6-Dinitrotoluene
Isophorone
Bis(2-Chloroethoxy)methane
Acridine
N-Nitrosodi-n-propylamine
N-Nitrosodiphenylamine
Anthraquinone
Azobenzene
Nitrobenzene
Pentachloronitrobenzene
Carbazole
Benzo[c]cinnoline

$\begin{array}{llllll}49391 & 119-91-5 & <150 & <50 & <50 & <50 \\ 49392 & 91-22-5 & <150 & <50 & <50 & <50 \\ 49393 & 229-87-8 & <150 & <50 & <50 & <50 \\ 49394 & 119-65-3 & <150 & 14 & <50 & <50 \\ 49395 & 121-14-2 & <150 & <50 & <50 & <50 \\ 49396 & 606-20-2 & <150 & <50 & <50 & <50 \\ 49400 & 78-59-1 & <150 & <50 & <50 & 80 \\ 49401 & 111-91-1 & <150 & <50 & <50 & <50 \\ 49430 & 260-94-6 & <150 & <50 & <50 & <50 \\ 49431 & 621-64-7 & <150 & <50 & <50 & <50 \\ 49433 & 86-30-6 & <150 & <50 & <50 & <50 \\ 49437 & 84-65-1 & <150 & <50 & <50 & <50 \\ 49443 & 103-33-3 & <150 & <50 & <50 & <50 \\ 49444 & 98-95-3 & <150 & <50 & <50 & <50 \\ 49446 & 82-68-8 & <150 & <50 & <50 & <50 \\ 49449 & 86-74-8 & <150 & <50 & <50 & <50 \\ 49468 & 230-17-1 & <150 & <50 & <50 & <50\end{array}$

